\title{
PRAVO NA PRISTUP INFORMACIJAMA KAO PRAVO ZAS̆TIĆENO EUROPSKOM KONVENCIJOM I DRUGIM MEĐUNARODNIM UGOVORIMA ZA ZAŠTITU LJUDSKIH PRAVA
}

Dr. sc. Lana Ofak, docentica

Pravni fakultet Sveučilišta u Zagrebu Zagreb

\author{
UDK: $342.738(4)$ \\ Ur.: 13. prosinca 2015. \\ Pr.: 5. travnja 2016. \\ Pregledni znanstveni rad
}

\section{Sažetak}

U radu se prikazuje način na koji je pravo na pristup informacijama zaštićeno u međunarodnim ugovorima za zaštitu ljudskih prava - Međunarodnom paktu o građanskim i političkim pravima te Američkom konvencijom za zaštitu ljudskih prava. Analizira se praksa Odbora za ljudska prava Ujedinjenih naroda te Međuameričkog suda za ljudska prava. Zatim se prikazuje razvoj pristupa Europskog suda za ljudska prava zaštiti prava na pristup informacijama prema članku 10. Europske konvencije za zaštitu ljudskih prava i temeljnih sloboda. Usporedba presuda Europskog suda s odlukama Odbora za ljudska prava te Međuameričkog suda dovodi do zaključka da postoje dodirne točke u načinu pružanja zaštite prava na pristup informacijama, ali i da je praksa Europskog suda u određenim pitanjima različita od Odbora za ljudska prava i Međuameričkog suda. Na kraju rada istražuje se praksa Ustavnog suda Republike Hrvatske u vezi s postupcima po Zakonu o pravu na pristup informacijama koji su prethodili ustavnosudskom postupku te se provodi analiza 49 odluka i rješenja Ustavnog suda donesenih u razdoblju od srpnja 2008. do srpnja 2014. Rad završava s određenim zaključcima o razlici uvjeta zaštite prava na pristup informacijama prema Ustavu Republike Hrvatske $i$ Europskoj konvenciji te razini zaštite toga prava koja bi se trebala pružiti.

Ključne riječi: pravo na pristup informacijama, sloboda izražavanja, Odbor za ljudska prava Ujedinjenih naroda, Međuamerički sud za ljudska prava, Europski sud za ljudska prava, Ustavni sud Republike Hrvatske. 


\section{UVOD}

Pravo na pristup informacijama prepoznato je u demokratskim zemljama kao preduvjet transparentnosti i odgovornosti vlasti koji štiti građane od lošeg upravljanja i korupcije vlasti. Nakon Drugog svjetskog rata međunarodni dokumenti za zaštitu ljudskih prava uključuju pravo na pristup informacijama kao osnovu demokratskih društava. ${ }^{1}$ Premda oni izrijekom ne propisuju pravo na pristup informacijama koje posjeduju tijela javne vlasti, razvija se konsenzus da je to pravo obuhvaćeno pravom na slobodu izražavanja, ${ }^{2}$ što će biti predmet analize u narednim poglavljima ovoga rada.

Od 2001. godine na snazi je Konvencija Gospodarske komisije Ujedinjenih naroda za Europu o pristupu informacijama, sudjelovanju javnosti u odlučivanju i pristupu pravosuđu u pitanjima okoliša. ${ }^{3}$ Međutim, ta Konvencija pravo na pristup informacijama uređuje samo u odnosu na informacije o okolišu. Stoga se prvim međunarodnim ugovorom kojim se eksplicite štiti pravo na pristup informacijama smatra Konvencija Vijeća Europe o pristupu službenim dokumentima ${ }^{4}$ iz 2009. godine. ${ }^{5} \mathrm{Na}$ razini Europske unije pravo na pristup dokumentima jedno je od temeljnih prava izričito uključenih u Povelju o temeljnim pravima Europske unije, ali odnosi se samo na dokumente institucija, tijela, ureda i agencija Unije, no ništa se ne spominje $u$ toj odredbi o dokumentima tijela javne vlasti država članica. ${ }^{6}$

Pod pravom na pristup informacijama, za potrebe ovoga rada, podrazumijevat će se to pravo prema definiciji propisanoj u Zakonu o pravu na pristup informacijama ${ }^{7}$ (dalje: ZPPI). Pravo na pristup informacijama obuhvaća pravo

1 Musa, A., Transparentnost - zašto i kako? u: Musa, A. (ur.), 5. Forum za javnu upravu Transparentnost u javnom upravljanju, Zagreb, Friedrich Ebert Stiftung, ured za Hrvatsku i Institut za javnu upravu, 2013., str. 14.

2 Coppel, P., Information rights: Law and practice, Oxford - Portland Oregon, Hart Publishing, 2014., str. 83.

3 Konvencija je stupila na snagu u odnosu na Republiku Hrvatsku 2007. godine (NN - MU, br. 1/2007).

4 Republika Hrvatska nije potpisnica Konvencije. Da bi stupila na snagu potrebno je da je ratificiraju još tri zemlje (potrebno je najmanje deset zemalja). V. $<$ http://conventions.coe. int $/$ Treaty $/$ Commun/ChercheSig.asp? $\mathrm{NT}=205 \& \mathrm{CM}=\& \mathrm{DF}=\& \mathrm{CL}=\mathrm{ENG}>$ (pristup: 18. rujna 2015.).

5 V.: Musa, A., op. cit., str. 14-15.; McDonagh, M., The Right to Information in International Human Rights Law, Human Rights Law Review 13(1), 2013., str. 28.; Gardašević, Đ., Transparentnost javne vlasti na lokalnoj i područnoj (regionalnoj) razini, u: Kregar, J. i dr., Decentralizacija, Zagreb, Centar Miko Tripalo, 2011., str. 148-149.

6 Članak 42. Povelje o temeljnim pravima Europske unije glasi: „Svaki građanin Unije i svaka fizička ili pravna osoba s boravištem ili sjedištem u nekoj državi članici ima pravo pristupa dokumentima institucija, tijela, ureda i agencija Unije neovisno o njihovu mediju." V. i članak 15. Ugovora o funkcioniranju Europske unije (bivši članak 255. Ugovora o Europskoj zajednici). Pravo pristupa dokumentima institucija, tijela, ureda i agencija Unije zasebno je uređeno, tj. odvojeno je od prava svake osobe na pristup svojem dosjeu (uz poštovanje zakonitih interesa povjerljivosti te profesionalne i poslovne tajne), koje je zaštićeno člankom 41. stavkom 2. točkom (b) Povelje u okviru jamstva prava na dobru upravu.

7 NN, br. $25 / 2013$ i $85 / 2015$. 
korisnika na traženje i dobivanje informacije kao i obvezu tijela javne vlasti da omogući pristup zatraženoj informaciji, odnosno da objavljuje informacije neovisno o postavljenom zahtjevu kada takvo objavljivanje proizlazi iz obveze određene zakonom ili drugim propisom (članak 5., točka 5. ZPPI-a).

U hrvatskoj znanstvenoj i stručnoj literaturi tema prava na pristup informacijama vrlo je kvalitetno zastupljena. ${ }^{8}$ Radi se o dinamičnoj problematici koja je u neprekidnom procesu razvoja - i s aspekta regulacije i s aspekta prakse tijela koja su ovlaštena provoditi nadzor nad ostvarivanjem prava na pristup informacijama. U tom vidu, u ovom će se radu pojasniti recentni pristup Europskog suda za ljudska prava (dalje i: Europski sud) zaštiti prava na pristup informacijama (v. poglavlje 3. ovog rada). Taj će se pristup sagledavati u okviru članka 10. Konvencije za zaštitu ljudskih prava i temeljnih sloboda ${ }^{9}$ (dalje: Europska konvencija ili Konvencija) koji jamči slobodu izražavanja. Međutim, za bolje razumijevanje prakse Europskog suda prethodno je potrebno prikazati način na koji je pravo na pristup informacijama zaštićeno u drugim međunarodnim ugovorima za zaštitu ljudskih prava (v. poglavlje 2. ovoga rada), jer se iz prakse različitih međunarodnih tijela nadležnih za razmatranje povreda ljudskih prava može razabrati smjer i razvoj njihove zaštite.

Prikaz razvoja prakse Europskog suda i drugih međunarodnih tijela za zaštitu ljudskih prava provest će se kako bi se utvrdilo u čemu su uvjeti zaštite prava na pristup informacijama različiti prema Ustavu Republike Hrvatske ${ }^{10}$ (dalje i: Ustav) u usporedbi sa zaštitom koja je zajamčena Europskom konvencijom. S tim u vezi, analizirat će se praksa Ustavnog suda Republike Hrvatske u vezi s postupcima ostvarivanja prava na pristup informacijama od 2008. do 2014. godine (v. poglavlje

8 V. primjerice (kronološki od novijih članaka): Podolnjak, R.; Gardašević, Đ., Great Expectations: The New Croatian Freedom of Information Act, Iustinianus Primus Law Review 6(10), 2014., str. 1-26.; Rajko, A., Novi Zakon o pravu na pristup informacijama - geneza i otvorena pitanja, Zbornik radova Pravnog fakulteta u Splitu 51(2), 2014., str. 415-427.; Rajko, A., Antinomije u hrvatskom zakonodavstvu na području informacijskog upravnog prava, u: Koprić, Ivan (ur.), Europeizacija hrvatske javne uprave, Zagreb, Pravni fakultet Sveučilišta, Studijski centar za javnu upravu i javne financije, 2014., str. 609-638.; Musa, A., op. cit., str. 7-26.; Šprajc, I., Obveze tijela javne vlasti prema hrvatskom Zakonu o pravu na pristup informacijama, Sveske za javno pravo 4(13), 2013., str. 21-31.; Gardašević, Đ., Transparentnost javne vlasti na lokalnoj i područnoj (regionalnoj) razini, u: Kregar, J. i dr., Decentralizacija, Zagreb, Centar Miko Tripalo, 2011., str. 135-158.; Đerđa, D.; Popovski, A., Postupak ostvarivanja prava na pristup informacijama kao posebni upravni postupak, Hrvatska pravna revija 11(1), 2011., str. 25-30.; Rajko, A., Implikacije uvrštavanja prava na pristup informacijama javnog sektora u Ustav Republike Hrvatske, Hrvatska javna uprava 10(3), 2010., str. 629-649.; Smerdel, B., Ustavna osnova prava javnosti na informaciju, Informator 55(5527), 2007., str. 1-2.; Smerdel, B.; Gardašević, Đ., The Notion of Security and Free Access to Information: Creation and Development of the Right of the Public to Know in European and Croatian Jurisprudence. Politics in Central Europe, The Journal of the Central European Political Science Association 2(2), 2007., str. 24-37.

9 Konvencija za zaštitu ljudskih prava i temeljnih sloboda i Protokoli broj 1, 4, 6, 7 i 11, NN MU, br. 18/1997, 6/1999 - pročišćeni tekst, 8/1999 - ispravak.

10 NN, br. 56/1990, 135/1997, 113/2000, 28/2001, 76/2010 i 5/2014. 
4. ovoga rada). ${ }^{11}$ Rad će završiti s određenim stajalištima o dosadašnjoj praksi Ustavnog suda i Europskog suda te razini zaštite prava na pristup informacijama koja bi se trebala pružiti.

\subsection{Osnovne karakteristike prava na pristup informacijama}

Za potrebe ovoga istraživanja, kao temeljne karakteristike prava na pristup informacijama, koje će se kroz praksu različitih tijela za zaštitu ljudskih prava sagledavati u narednim poglavljima, uzet će se sljedeća četiri obilježja. ${ }^{12}$ Kao prvo, pravo na pristup informacijama zasebno je ljudsko pravo, što znači da ima svoju intrinzičnu vrijednost kao ljudsko pravo, a ne samo instrumentalnu u smislu da služi ostvarenju drugih ljudskih prava. U Hrvatskoj je Promjenama Ustava iz $2010 .{ }^{13}$ pravo na pristup informacijama postalo izričito ustavno pravo, a zajamčeno je u dijelu Ustava koji se odnosi na osobne i političke slobode i prava. ${ }^{14}$ Do tada je jamstvo pristupa informacijama bilo izričito dano samo novinarima (članak 38 . stavak 3.) radi jačanja njihova položaja kao posrednika u obavještavanju javnosti, međutim to ne znači da ostale osobe to pravo nisu imale i prije Promjena Ustava. ${ }^{15}$

Kao drugo, pravo na pristup informacijama pripada svakoj osobi bez diskriminacije. Ustav propisuje pravo na pristup informacijama bez definiranja adresata toga prava, što je u skladu s člankom 2. stavkom 1. Konvencije o pristupu službenim dokumentima koji propisuje da se pravo jamči svakome, bez diskriminacije po bilo kojoj osnovi. To je zatim razrađeno u ZPPI-u koji korisnika prava na pristup informacijama definira kao svaku domaću ili stranu fizičku i pravnu osobu (članak 5. točka 1.). ${ }^{16}$ Sukladno načelu javnosti i slobodnog pristupa, informacije su

11 Autorica se zahvaljuje Sanji Trgovac, voditeljici Centra za evidenciju i dokumentaciju Ustavnog suda Republike Hrvatske na svesrdnoj pomoći u pronalaženju i prikupljanju relevantne prakse Ustavnog suda.

$12 \mathrm{U}$ literaturi se često navodi više temeljnih karakteristika (v. primjerice načela zakonodavstva o pristupu informacijama: Musa, A., op. cit., str. 13.). Međutim, sagledavanje svih njih znatno bi prekoračilo opseg ovoga rada. McDonagh (op. cit., str. 45.) navodi četiri karakteristike kroz koje razmatra opseg prava na pristup informacijama u međunarodnom pravu: kontekst u kojem se to pravo može koristiti, kategorije korisnika toga prava, narav informacije koja se može tražiti te svrha zbog koje se traži pristup.

13 NN, br. 76/2010.

14 Članak 38. stavak 4. Ustava glasi: „Jamči se pravo na pristup informacijama koje posjeduju tijela javne vlasti. Ograničenja prava na pristup informacijama moraju biti razmjerna naravi potrebe za ograničenjem u svakom pojedinom slučaju te nužna u slobodnom i demokratskom društvu, a propisuju se zakonom." O posljedicama uvrštavanja prava na pristup informacijama u Ustav, v. Rajko, A., Implikacije..., op. cit.

15 Smerdel (op. cit., str. 1-2.) te Smerdel i Gardašević (op. cit., str. 29-34.) pojašnjavaju da teleološko tumačenje, povijesna metoda i komparativna metoda, polazeći od cjeline ustavnog koncepta, osobito od temeljnih vrednota vladavine prava i demokratskog višestranačkog sustava, ukazuju da je pravo javnosti na pristup informacijama bilo sadržano u nizu relevantnih odredaba Ustava Republike Hrvatske i prije Promjene Ustava 2010. godine.

16 Budući da pravo na ponovnu uporabu informacija neće biti predmet ovog rada, iz pojedinih odredaba ZPPI-a izostavit će se dijelovi koji se odnose na ponovnu uporabu informacija. 
dostupne svakoj domaćoj ili stranoj fizičkoj i pravnoj osobi u skladu s uvjetima i ograničenjima ZPPI-a (članak 6.). Prema načelu jednakosti pravo na pristup informacijama pripada svim korisnicima na jednak način i pod jednakim uvjetima te su korisnici ravnopravni u njegovu ostvarivanju (članak 8. stavak 1.). Dodatno je propisano da tijela javne vlasti ne smiju staviti korisnike u neravnopravan položaj, a osobito na način da se pojedinim korisnicima informacija pruža prije nego ostalima ili na način kojim im se posebno pogoduje (članak 8. stavak 2.).

Kao treću karakteristiku bitno je istaknuti da ne postoje ograničenja u vezi s naravi (kategorije, karaktera, vrste) informacije koja se traži. ${ }^{17}$ Konvencija o pristupu službenim dokumentima pod službenim dokumentima podrazumijeva sve informacije snimljene u bilo kojem obliku, pripremljene ili primljene i u posjedu tijela javne vlasti (članak 1. stavak 2.b). Ustav ništa ne propisuje o kakvim se informacijama radi, već samo da ih posjeduju tijela javne vlasti. Međutim, u vezi s pitanjem karaktera informacije došlo je do izmjena i dopuna ZPPI-a u srpnju 2015. ${ }^{18}$ Prema mišljenju predlagatelja izmjena i dopuna ZPPI-a dosadašnja definicija informacije bila je previše široka jer je zahtijevala samo da se radi o materijaliziranoj informaciji (dokument, zapis, dosje, registar), dok svrha nastanka nije bila relevantna. ${ }^{19}$ Također je napomenuto da za razliku od zakona drugih država, u definiranju pojma ,informacija“ dosadašnji zakon nije koristio riječ „javna“ ili „službena“ informacija kako bi označio karakter informacije. Sukladno novoj definiciji informacija je svaki podatak koji posjeduje tijelo javne vlasti u obliku dokumenta, zapisa, dosjea, registra, neovisno o načinu na koji je prikazan (napisani, nacrtani, tiskani, snimljeni, magnetni, optički, elektronički ili neki drugi zapis), koji je tijelo izradilo samo ili u suradnji s drugim tijelima ili dobilo od druge osobe, a nastao je u okviru djelokruga ili u vezi s organizacijom i radom tijela javne vlasti (članak 3. točka 3.). ${ }^{20} \mathrm{U}$ objašnjenju pojedinih odredaba Zakona o izmjenama i dopunama ZPPI-a navedeno je da prijašnja definicija ne razlikuje i ne izuzima informacije javnopravnog tijela nastale u obavljanju komercijalnog dijela posla, kao što bi to bila, npr. trgovačka društva u većinskom vlasništvu države, a koja ujedno u dijelu svoje aktivnosti djeluju na tržištu kao i drugi privatnopravni subjekti. ${ }^{21}$ Naime, zbog široko postavljene definicije tijela javne vlasti, u taj pojam mogu potpadati i pravne osobe koje obavljaju javne poslove u odnosu na jedan dio svojih djelatnosti, a da je drugi dio njihovih djelatnosti privatne naravi. Stoga se novom definicijom

17 McDonagh, M., op. cit., str. 47.

18 NN, br. 85/2015.

19 Vlada Republike Hrvatske, Konačni prijedlog Zakona o izmjenama i dopunama Zakona o pravu na pristup informacijama (P.Z.E. br. 832), 2015., str. 18.

20 U Objedinjenim pristiglim primjedbama i očitovanjima s obrazloženjima o njihovu (ne) prihvaćanju navedeno je da predložena izmjena ne predstavlja sužavanje definicije "informacije" već njezino preciziranje vodeći se dosadašnjom praksom (v.

$<$ https://uprava.gov.hr/pristup-informacijama/savjetovanje-sa-zainteresiranom-javnoscu/ okoncana-savjetovanja/nacrt-prijedloga-zakona-o-izmjenama-i-dopunama-zakona-o-pravuna-pristup-informacijama/14065> (pristup: 18. rujna 2015.).

21 Vlada Republike Hrvatske, loc. cit. 
preciziralo da se jamstvo prava na pristup informacijama primjenjuje samo na one informacije koje su nastale u okviru djelokruga ili u vezi s organizacijom i radom u onom dijelu aktivnosti zbog kojih se neko tijelo smatra tijelom javne vlasti.

U pogledu naravi informacije potrebno je istaknuti još jednu osobitost hrvatskog pravnog uređenja. Naime, hrvatski zakonodavac jasno razlikuje pripada li korisniku pravo na pristup prema nekom drugom pravnom temelju. Bez obzira na izričitu odredbu ZPPI-a da se njegove odredbe ne primjenjuju na stranke u sudskim, upravnim i drugim na zakonu utemeljenim postupcima, kojima je dostupnost informacija iz tih postupaka utvrđena propisom (članak 1. stavak 3.), u praksi su se često javljali slučajevi podnošenja zahtjeva za pristup informacijama kojima se tražilo, primjerice, uvid u cjelokupni spis nekog predmeta u kojem je podnositelj stranka pred nekim tijelom javne vlasti, zatim uvid u vlastite podatke, davanje pojašnjenja ili uputa vezanih uz ostvarivanje nekog prava ili ispunjenje neke obveze te tumačenje nekog propisa. ${ }^{22}$ Budući da se navedena prava mogu ostvariti u drugim uređenim postupcima (npr. uvid u spis) ili se odnose na druge obveze tijela javne vlasti (npr. pružanje informacija o načinu ostvarivanja prava), u zakonske odredbe ugradila se i negativna definicija zahtjeva za pristup informacijama. ${ }^{23}$ Sukladno novoj negativnoj definiciji, ne smatra se zahtjevom za pristup informacijama traženje uvida u cjelokupni spis predmeta, objašnjenja ili uputa vezanih uz ostvarivanje nekog prava ili izvršavanje obveze, izrade analize ili tumačenja nekog propisa, kao ni stvaranje nove informacije (članak 18. stavak 5.). Kad obavještava korisnika da se podnesak ne smatra zahtjevom u smislu članka 18. stavka 5. ZPPI-a tijelo javne vlasti ne donosi rješenje o zahtjevu, ali je dužno uputiti korisnika na način ostvarivanja njegova traženja (članak 23. stavak 1. točka 6.).

I naposljetku, kao četvrta karakteristika prava na pristup informacijama koja će se razmatrati u ovom radu jest nepostojanje obveze korisnika da navede razlog zbog kojeg traži pristup informacijama. Sukladno članku 4. stavku 1. Konvencije o pristupu službenim dokumentima, podnositelj zahtjeva za pristup službenom dokumentu nije obvezan navesti razloge za pristup tom službenom dokumentu. Jednako tako, prema članku 18. stavku 4. ZPPI-a podnositelj zahtjeva nije obvezan navesti razloge zbog kojih traži pristup informaciji, niti je obvezan pozvati se na primjenu ZPPI-a.

Navedene karakteristike prava na pristup informacijama ne smiju se shvatiti tako da sugeriraju da bi to pravo trebalo biti apsolutno. ${ }^{24}$ Već i sam Ustav (druga rečenica članka 38. stavka 4.) predviđa mogućnost ograničenja toga prava, s time da se moraju poštovati određeni uvjeti; ograničenje mora biti: (a) propisano zakonom, (b) razmjerno naravi potrebe za ograničenjem u svakom pojedinom slučaju te (c) nužno u slobodnom i demokratskom društvu. I prema članku 3. Konvencije o pristupu službenim dokumentima moguća su ograničenja tog pristupa.

22 Povjerenica za informiranje, Što donose izmjene i dopune Zakona o pravu na pristup informacijama, <http://www.pristupinfo.hr/wp-content/uploads/2015/08/\%C5\%A0to-donoseizmjene-ZPPI-85-2015.docx> (pristup: 9. listopada 2015.).

23 Ibid.; Vlada Republike Hrvatske, op. cit., str. 21.

24 McDonagh, M., op. cit., str. 45. 
U narednom poglavlju ovoga rada analizirat će se opseg zaštite prava na pristup informacijama u praksi Odbora za ljudska prava Ujedinjenih naroda te Međuameričkog suda za ljudska prava sa stajališta prethodno navedenih temeljnih karakteristika toga prava.

\section{MEDUNARODNI UGOVORI ZA ZAŠTITU LJUDSKIH PRAVA I PRAVO NA PRISTUP INFORMACIJAMA}

Opća deklaracija o pravima čovjeka, ${ }^{25}$ koju je donijela Opća skupština Ujedinjenih naroda (dalje: UN) 1948. godine, poslužila je kao uzor za buduće pravno obvezujuće međunarodne ugovore za zaštitu ljudskih prava. Ona proglašava načela koja su kasnije detaljnije utvrđena u dvjema konvencijama (dva pakta) o pravima čovjeka. ${ }^{26}$

Opća deklaracija u svom članku 19. propisuje da svatko ima pravo na slobodu mišljenja i izražavanja. To pravo uključuje slobodu zadržavanja mišljenja bez uplitanja i slobodu traženja, primanja i širenja informacija i ideja putem bilo kojeg medija i bez obzira na granice. Nakon usvajanja Opće deklaracije pristupilo se izradi međunarodnog ugovora koji bi njezine opće odredbe pretvorio u obvezujuće dužnosti. ${ }^{27}$ Prema odredbi članka 19. Opće deklaracije, oblikovan je članak 19. Međunarodnog pakta o građanskim i političkim pravima ${ }^{28}$ koji pod pravom na slobodu izražavanja isto navodi slobodu traženja, primanja i širenja informacija. ${ }^{29}$ Države koje su ratificirale ili pristupile Prvom fakultativnom protokolu uz Međunarodni pakt o građanskim i političkim pravima (stupio na snagu 1976.) (30 $^{30}$ prihvatile su da osobe pod njihovom jurisdikcijom mogu podnositi Odboru za ljudska prava UN-a pritužbe (priopćenja) o povredi odredaba toga Pakta.

Sloboda izražavanja i sloboda informiranja već se dugo povezuju u međunarodnim dokumentima vezanim uz zaštitu ljudskih prava. Na prvom

$25 \mathrm{NN}-\mathrm{MU}$, br. $143 / 2009$.

26 Andrassy, J.; Bakotić, B.; Seršić, M.; Vukas, B., Međunarodno pravo 1, Zagreb, Školska knjiga, 2010., str. 372 .

27 Ibid., str. 373.

$28 \mathrm{NN}-\mathrm{MU}$, br. 12/1993.

29 Članak 19. glasi:

„1. Svatko ima pravo zadržati svoja uvjerenja bez miješanja sa strane.

2. Svatko ima pravo na slobodu izražavanja. To pravo obuhvaća slobodu traženja, primanja i širenja informacija i ideja svake vrste, usmeno, pismeno, tiskom ili umjetničkim oblikom, ili kojim drugim sredstvom prema svom osobnom izboru i bez obzira na granice.

3. Ostvarenje prava predviđenih stavkom 2. ovoga članka nosi sa sobom posebne dužnosti i odgovornosti. Stoga se ono može podvrgnuti određenim ograničenjima, ali samo takvima koja su predviđena zakonom i koja su prijeko potrebna radi:

a) poštivanja prava i ugleda drugih;

b) zaštite državne sigurnosti, javnog reda, zdravlja ili morala.“

30 Republika Hrvatska stranka je Međunarodnog pakta o građanskim i političkim pravima od 8. listopada 1991. godine na temelju notifikacije o sukcesiji (NN - MU, br. 12/1993) te Prvog fakultativnog Protokola od 1995. godine (NN - MU, br. 7/1995). 
zasjedanju 1946. godine Opća skupština UN-a usvojila je brojne rezolucije, ${ }^{31}$ među kojima i Rezoluciju 59(I) kojom poziva na međunarodnu konferenciju o slobodi informiranja. ${ }^{32} \mathrm{U}$ Rezoluciji se navodi da je sloboda informiranja temeljno ljudsko pravo i osnova svih sloboda kojima se UN posvećuje, a pod slobodom informiranja podrazumijeva se pravo na prikupljanje, prenošenje i objavljivanje vijesti bilo gdje bez sputavanja. Konferencija o slobodi informiranja koja se održala 1948. u Ženevi imala je zadatak pripremiti Konvenciju o slobodi informiranja koja se uglavnom odnosila na slobodu protoka informacija preko granica, a ne na pristup informacijama koje posjeduju tijela javne vlasti. ${ }^{33}$ Konferencija se osobito bavila problematikom ratne propagande te netočnih i iskrivljenih informacija. Pripremljena su tri nacrta konvencija: (1) tzv. Konvencija Sjedinjenih Američkih Država o prikupljanju i međunarodnom prijenosu vijesti, (2) tzv. Francuska konvencija o međunarodnom pravu na ispravak te (3) tzv. Britanska konvencija o općim načelima slobode informiranja. ${ }^{34}$ Godine1949., kao rezultat spajanja prva dva nacrta, usvojen je Nacrt Konvencije o međunarodnom prijenosu vijesti i pravu na ispravak. ${ }^{35}$ No on nije stupio na snagu, već je 1953. usvojena Konvencija o međunarodnom pravu na ispravak. ${ }^{36}$ Ta je Konvencija stupila na snagu 1962., a ima samo 17 stranaka. Što se tiče trećeg nacrta o načelima slobode informiranja, proces usvajanja Nacrta Konvencije o slobodi informiranja nikada nije bio završen. ${ }^{37}$

Komisija za ljudska prava UN-a, koja je od 1946. do 2006. djelovala kao glavni mehanizam UN-a za promicanje i zaštitu ljudskih prava, ${ }^{38}$ 1993. godine uspostavila je mandat Posebnog izvjestitelja za promicanje i zaštitu slobode mišljenja i izražavanja. U njegovim izvješćima zauzima se stajalište da članak 19. Međunarodnog pakta o građanskim i političkim pravima o slobodi traženja, primanja i širenja informacija nameće pozitivnu obvezu državama da osiguraju pristup informacijama, osobito u odnosu na informacije koje posjeduje Vlada ${ }^{39}$ te

31 V. General Assembly Resolutions 1st Session, <http://www.un.org/documents/ga/res/1/ares1. htm> (pristup: 9. listopada 2015.)

32 General Assembly, Resolution 59 (I) Calling of an International Conference on Freedom of Information, 14 December 1946.

33 Bishop, C. A., Internationalizing the Right to Know: Conceptualizations of Access to Information in Human Rights Law, Dissertation, University of North Carolina at Chapel Hill, 2009., str. 5.

34 Whitton, J. B., The United Nations Conference on Freedom of Information and the Movement Against International Propaganda. American Journal of International Law 43(1), 1949., str. 74.

35 V. Resolutions and Decisions adopted by the General Assembly during its 3rd session, A/ RES/277(III) A-C, <http://www.un.org/documents/ga/res/3/ares3.htm> (pristup: 9. listopada 2015.).

36 Convention on the International Right of Correction, New York, 31 March 1953 (United Nations, Treaty Series, vol. 435, p. 191).

37 Bishop, C. A., loc. cit.

38 Godine 2006. Komisija je zamijenjena Vijećem za ljudska prava.

39 V. Report of the Special Rapporteur on the right to seek and receive information, the media in countries of transition and in elections, the impact of new information technologies, national security, and women and freedom of expression, E/CN.4/1998/40, 28 January 1998, točka 14., str. 4. 
da se pravo na pristup informacijama koje posjeduju tijela javne vlasti može lako deducirati iz članka 19. Međunarodnoga pakta. ${ }^{40}$

Za razliku od izvješća Posebnog izvjestitelja koji se već u drugoj polovini 90-tih godina počeo zalagati za pravo na pristup informacijama, praksa Odbora za ljudska prava UN-a postupno se razvijala u smjeru tumačenja prava na pristup informacija pod okriljem slobode izražavanja. Godine 2009. u predmetu S. B. protiv Kirgistana ${ }^{41}$ Odbor za ljudska prava u svojoj odluci o dopuštenosti priopćenja „napominje da podnositelj nije obrazložio zašto baš on, osobno, treba informacije u pitanju; umjesto toga, on je tvrdio da je to stvar javnog interesa. Pod tim okolnostima, a u nedostatku bilo koje druge relevantne informacije, Odbor smatra da predmetno priopćenje predstavlja actio popularis, te da je stoga nedopušteno na temelju članka 1. Fakultativnog protokola." ${ }^{\text {"42 }} \mathrm{O}$ vrlo sličnom predmetu Odbor je ponovo odlučivao 2011. godine (Toktakunov protiv Kirgistana) ${ }^{43}$ Odbor je utvrdio da ,pravo tražiti i primiti informacije kako je sadržano u članku 19. stavku 2. Pakta, uključuje i pravo pojedinca da primi informacije koje posjeduje Država, uz iznimke dopuštene ograničenjima koja su utvrđena u Paktu. Odbor napominje da informacije moraju biti dostupne bez potrebe dokazivanja izravnog interesa ili osobne uključenosti za njihovo primanje, osim ako se primjenjuje legitimno ograničenje. Odbor također podsjeća na svoje stajalište u odnosu na tisak i medije koje uključuje pravo sudionika u medijima na pristup informacijama o javnim poslovima i pravo javnosti da dobije podatke od medija. Nadalje primjećuje da su među funkcijama tiska i medija stvaranje foruma za javnu raspravu i formiranje javnog ili, u tu svrhu, individualnog mišljenja o pitanjima od legitimnog javnog interesa, poput primjene smrtne kazne. Odbor smatra da ostvarenje tih funkcija nije ograničeno na medije ili profesionalne novinare te da ih također mogu ostvarivati, primjerice, javne udruge ili pojedinci.“"44 Odbor je također objasnio zašto smatra da se ovaj predmet

40 V. Report of the Special Rapporteur on implementing the right of access to information and protection and security of media professionals, E/CN.4/2005/64, 17 December 2004, točka 39., str. 10.

41 U ovom predmetu radilo se o aktivistu za ljudska prava koji je zatražio informacije od Ministarstva pravosuđa u vezi s primjenom smrtne kazne u Kirgistanu. Naime, zanimao ga je broj osoba koje su osuđene na smrtnu kaznu nakon što je novim Ustavom ukinuta smrtna kazna.

42 Human Rights Committee, CCPR/C/96/D/1877/2009, 25 August 2009, Communication No. $1877 / 2009$, S. B. v. Kyrgyzstan, par. 4.2.

43 Youth Human Rights Group (YHRG), udruga za koju podnositelj priopćenja radi kao pravni savjetnik, zatražila je od Ministarstva pravosuđa da joj se pruže informacije o broju osoba osuđenih na smrt u Kirgistanu na dan 31. prosinca 2003. godine, kao i broj osoba osuđenih na smrt, a koje se trenutno nalaze u zatvorskom sustavu. Ovaj zahtjev za informacijom podnesen je u skladu s člankom 17.8 Dokumenta sa sastanka Konferencije o sigurnosti i suradnji u Europi u Kopenhagenu o ljudskoj dimenziji (29. lipnja 1990.) (Dokument iz Kopenhagena), prema kojem su države članice pristale javnosti staviti na raspolaganje informacije o primjeni smrtne kazne. Ministarstvo pravosuđa odbilo je dati ove informacije, zbog klasifikacije kao „povjerljivo“ i ,vrlo tajno“ sukladno propisima u Kirgistanu.

44 Human Rights Committee, CCPR/C/101/D/1470/2006, 21 April 2011, Communication No. 1470/2006, Toktakunov v. Kyrgyzstan, par. 6.3. 
razlikuje od S. B. protiv Kirgistana. Podnositelj priopćenja je pravni savjetnik u udruzi za zaštitu ljudskih prava te „kao takav može se smatrati da ima posebnu funkciju „čuvara“ o pitanjima od javnog interesa“ ${ }^{45}$ Stoga je Odbor zaključio da je podnositelj potkrijepio, u svrhu odlučivanja o dopuštenosti njegova priopćenja, „da je on kao pojedini pripadnik javnosti, izravno pogođen odbijanjem tijela vlasti države stranke da mu pruži, na zahtjev, informacije o primjeni smrtne kazne.“46

Vezano uz razmatranje merituma, Odbor je napomenuo sljedeće: „Kada, u ostvarivanju funkcija „,̌uvara“ o pitanjima od legitimnog javnog interesa, udruge ili privatni pojedinci trebaju pristupiti informacijama koje posjeduje država, kao u ovom slučaju, takvi zahtjevi za informacije nalažu sličnu zaštitu Pakta kao što se pruža novinarima. Davanje informacija pojedincu može, pak, omogućiti da cirkuliraju u društvu, tako da se društvo može upoznati s informacijama, imati pristup njima, i procjenjivati ih. Na taj način, pravo na slobodu mišljenja i izražavanja obuhvaća zaštitu prava na pristup informacijama koje posjeduje država, što također jasno uključuje dvije dimenzije prava na slobodu mišljenja i izražavanja, individualnu i društvenu, koje istodobno moraju biti zajamčene od strane države. U tim okolnostima, Odbor smatra da je država stranka imala obvezu ili pružiti podnositelju tražene informacije ili opravdati bilo koja ograničenja prava na primanje informacija koje posjeduje država prema članku 19. stavku 3. Pakta. “47 Iduće je pitanje jesu li u tom predmetu ograničenja prava na pristup informacijama bila opravdana temeljem članka 19. stavka 3. Pakta prema kojemu ona moraju biti propisana zakonom i nužna zbog: (a) zaštite prava i ugleda drugih i (b) zaštite državne sigurnosti, javnog reda, javnog zdravlja ili morala. U tom pogledu Odbor „ponavlja stav naveden u Rezoluciji Komisije za ljudska prava br. 2003/67 i 2004/60 te Dokumentu iz Kopenhagena (...) da javnost ima legitimni interes za pristup informacijama o primjeni smrtne kazne i zaključuje da se, u nedostatku bilo kakvih relevantnih objašnjenja od države stranke, ograničenja na ostvarivanje prava podnositelja na pristup informacijama o primjeni smrtne kazne koje posjedu tijela javne vlasti ne mogu smatrati nužnim radi zaštite nacionalne sigurnosti ili javnog poretka, javnog zdravlja ili morala ili radi poštivanja prava i ugleda drugih. ${ }^{* 48}$ Stoga je Odbor zaključio da su podnositeljeva prava iz članka 19. stavka 2. Pakta bila povrijeđena u ovom slučaju. ${ }^{49}$ Nakon tog predmeta nije bilo više slučajeva pred Odborom za ljudska prava u vezi s povredom prava na pristup informacijama, osim jednog slučaja koji se odnosio na odbijanje akreditacije novinarke za Nacionalnu

45 Ibid. Međutim McDonagh (op. cit., str. 32) smatra da je Odbor za ljudska prava jednako mogao zaključiti i o S. B.-u koji je također bio aktivist za ljudska prava. Zasigurno je na promjenu stajališta Odbora utjecala presuda Europskog suda za ljudska prava u predmetu Társaság A Szabadságjogokért protiv Mađarske (v. poglavlje 3. ovog rada), kao i praksa Međuameričkog suda za ljudska prava (v. dolje). Dio obrazloženja odluke Odbora za ljudska prava doslovce je kopirano iz presude u predmetu Claude Reyes i drugi protiv Čilea.

46 Ibid.

47 Ibid., par. 7.4.

48 Ibid., par. 7.7.

49 Ibid., par. 7.8. 
skupštinu..$^{50}$ Ostali predmeti koje je Odbor do početka rujna 2015. godine razmatrao u okviru slobode informiranja odnosili su se uglavnom na zabranu javnih izlaganja, okupljanja, mirnih prosvjeda, zapljene brošura, uhićivanja zbog mirnog okupljanja te kažnjavanja za dijeljenje letaka.

Na regionalnoj razini, o zaštiti prava na pristup informacijama raspravljalo se i pod okriljem Američke konvencije o ljudskim pravima koja je 1969. godine usvojena u okviru Organizacije američkih država. Američka konvencija o ljudskim pravima stupila je na snagu 1978. te trenutno ima 23 stranke od ukupno 35 američkih država koje su članice Organizacije američkih država. ${ }^{51}$ Njezin članak 13. jamči slobodu mišljenja i izražavanja. ${ }^{52}$ Usporedbom navedenoga članka te članka 19. Međunarodnog pakta o građanskim i političkim pravima uočavaju se sličnosti. U oba međunarodna ugovora sloboda traženja informacija uključena je uz slobodu primanja i širenja informacija. I ograničenja su slično oblikovana. Razlika je u tomu što Američka konvencija sadrži izričitu odredbu kojom se isključuje mogućnost prethodne cenzure te dodatne stavke o zabrani neizravnih metoda i sredstava ograničavanja prava na izražavanje i u iznimnim slučajevima kada prethodna cenzura može biti dopuštena.

Godine 1959. osnovana je Međuamerička komisija za ljudska prava kao nezavisno tijelo Organizacije američkih država za promicanje i zaštitu ljudskih prava. Ona može primati i razmatrati pojedinačne pritužbe zbog povrede ljudskih

50 Human Rights Committee, CCPR/C/111/D/1985/2010, 26 August 2014, Communication No. 1985/2010, Koktish v. Belarus. Za pregled prakse Odbora za ljudska prava korišteno je pretraživanje baze UN Treaty Body Database, <http://tbinternet.ohchr.org/SitePages/Home. aspx> (pristup: 9. listopada 2015.).

51 Trinidad i Tobago (1998.) te Venezuela (2012.) otkazali su Američku konvenciju. V. <http:// www.oas.org/dil/treaties_B-32_American_Convention_on_Human_Rights_sign.htm> (pristup: 9. listopada 2015.)

52 Članak 13. Američke konvencije o ljudskim pravima glasi: „1. Svatko ima pravo na slobodu mišljenja i izražavanja. To pravo uključuje slobodu traženja, primanja i širenja informacija i ideja svake vrste, bez obzira na granice, usmeno, pismeno, tiskom, umjetničkom obliku ili bilo kojim drugim sredstvom prema vlastitom izboru.

2. Ostvarivanje prava predviđenog u prethodnom stavku ne može se podvrgnuti prethodnoj cenzuri, ali može se podvrgnuti naknadnom nametanju odgovornosti, koje se izrijekom ustanovljuje zakonom u mjeri potrebnoj da se osigura:

a. poštovanje prava ili ugleda drugih; ili

b. zaštita nacionalne sigurnosti, javnog reda ili javnog zdravlja ili morala.

3. Pravo izražavanja ne može se ograničiti neizravnim metodama i sredstvima, kao što su zloupotrebe vladine ili privatne kontrole nad tiskom, frekvencijama emitiranja ili opremi koja se koristi u širenju informacija, ili bilo kojim drugim sredstvima kojima se nastoji priječiti komunikacija i cirkulacija ideja i mišljenja.

4. Neovisno o odredbama stavka 2. ovoga članka, javna zabava može temeljem zakona biti podvrgnuta prethodnoj cenzuri isključivo u svrhu reguliranja njihovog pristupa radi moralne zaštite djece i adolescenata.

5. Svako poticanje na rat i bilo koje zagovaranje nacionalne, rasne ili vjerske mržnje koji čine poticanje na nezakonito nasilje ili na bilo koje druge slične radnje protiv bilo koje osobe ili skupine osoba na bilo kojoj osnovi, uključujući i rasu, boju kože, religiju, jezik ili nacionalno podrijetlo, smatrat će se djelom kažnjivom po zakonu." 
prava. Ako država ne ispuni njezine preporuke, Međuamerička komisija ima ovlast podnijeti predmet Međuameričkom sudu za ljudska prava (uspostavljen 1979., dalje: Međuamerički sud). Za međunarodni razvoj prava na pristup informacijama iznimno je važna presuda Međuameričkog suda iz 2006. godine u predmetu Claude Reyes i drugi protiv Čilea. ${ }^{53}$ Međuamerički sud zaključio je da „izričitim propisivanjem prava „traženja” i ,primanja” „informacije”, članak 13. Konvencije štiti pravo svakog pojedinca da zatraži pristup informacijama koje posjeduje država, uz iznimke dopuštene ograničenjima utvrđenima u Konvenciji. Prema tome, ovaj članak štiti pravo pojedinca primati takve informacije i pozitivnu obvezu države da ih pruži, tako da pojedinac može imati pristup takvim informacijama ili dobiti odgovor koji uključuje obrazloženje kada je, iz bilo kojeg razloga koji je dopušten Konvencijom, državi dopušteno ograničiti pristup informacijama u konkretnom slučaju." ${ }^{54}$ Budući da je presuda Međuameričkog suda prva presuda u kojoj je jedno međunarodno tijelo utvrdilo da je pravo na pristup informacijama koje posjeduje država sadržano u jamstvu slobode izražavanja, jasno se može zaključiti o njezinu utjecaju na druge međunarodne forume. ${ }^{55}$

Vezano uz pitanje opravdanosti ograničenja prava na pristup informacijama u tom konkretnom slučaju, Međuamerički sud je utvrdio da „država nije dokazala da je ograničenje odgovaralo svrsi koja je dopuštena Američkom konvencijom, niti da je to bilo nužno u demokratskom društvu, budući da tijelo nadležno odgovoriti na zahtjev za informacijama nije donijelo obrazloženu odluku u pisanom obliku kojom bi priopćilo razloge za ograničavanje pristupa tim informacijama u konkretnom slučaju." ${ }^{56} \mathrm{U}$ tom pogledu, Sud smatra da se uspostavljanjem ograničenja prava na pristup informacijama putem prakse tijela javne vlasti, a pritom ne poštujući odredbe Konvencije, stvara plodno tlo za diskrecijsko i proizvoljno postupanje države u klasificiranju informacija kao tajnih ili povjerljivih te dovodi do pravne nesigurnosti u vezi s ostvarivanjem tog prava i ovlasti države da ga ograničava. ${ }^{57}$ Dodatno, Međuamerički sud je iz istog razloga što nije donesena obrazložena odluka u pisanom obliku presudio i povredu članka 8. stavka 1. Američke konvencije kojom

53 Slučaj se odnosio na zahtjev za pristup informacijama o projektu krčenja šuma podnesenom čileanskom Odboru za strana ulaganja. Zatražene informacije odnosile su se na ugovor o stranim ulaganjima sklopljen između države, dva strana društva te jednog čileanskog društva za provedbu projekta eksploatacije šume koji je izazvao znatnu javnu raspravu zbog svoga mogućeg štetnog utjecaja na okoliš. Čileanski Odbor za strana ulaganja pružio je određene informacije, a u vezi s odbijanjem preostalog dijela nije donio pisanu odluku kojom bi obrazložio razloge ograničavanja pristupa preostalom dijelu informacija. Pravna sredstva koja su podnositelji podnijeli pred domaćim sudovima bila su odbačena kao nedopuštena.

54 Inter-American Court of Human Rights, Claude-Reyes et al. v. Chile, Judgment of September 19, 2006., par. 77.

55 Preostali dio paragrafa 77. presude identičan je pojedinim dijelovima već citiranog obrazloženja iz odluke Odbora za ljudska prava u predmetu Toktakunov protiv Kirgistana (2011.).

56 Claude-Reyes et al. v. Chile, op. cit., par. 95.

57 Ibid., par. 98. 
se jamči pravo na pošteno suđenje. ${ }^{58}$ Takva odluka morala bi pružati informacije o razlozima i pravnim normama na kojima se temelji odluka da se u konkretnom slučaju uskrati dio informacija te kojima bi se utvrdilo je li to ograničenje sukladno uvjetima koji su propisani u Konvenciji. Stoga je Međuamerički sud zaključio da je odluka tijela javne vlasti bila arbitrarna te da nije bila sukladna članku 8. stavka 1. Američke konvencije koji štiti jamstvo da ona mora biti obrazložena. ${ }^{59}$

Nakon presude u predmetu Claude Reyes i drugi protiv Čilea, Međuamerički sud odlučivao je o još jednom bitnom slučaju - Gomes Lund $i$ drugi protiv Brazila - vezanom uz pristup informacijama o arbitrarnom pritvaranju, mučenju i nestanku 70 osoba ${ }^{60}$ Međuamerički sud ponovio je svoje stajalište da najbliža obitelj ima pravo znati istinu o žrtvama, a dužnost istrage je mjera reparacije, s obzirom na potrebu da se popravi šteta povrede prava znati istinu. U tom predmetu, pravo znati istinu povezano je s pravom traženja i primanja informacija zajamčenom u članku 13. Američke konvencije. ${ }^{61} \mathrm{~S}$ tim u vezi Međuamerički sud izrazio je sljedeće stajalište: „Prema mišljenju ovog suda, država ne može tražiti zaštitu tvrdeći da ne postoje traženi dokumenti, već, naprotiv, mora utvrditi razlog za uskraćivanje pružanja tih informacija, pokazujući da je usvojila sve mjere temeljem svojih ovlasti kako bi dokazala da, u stvari, zatražene informacije ne postoje. Bitno je da, kako bi se zajamčilo pravo na informacije, tijela javne vlasti postupaju u dobroj vjeri i marljivo obavljaju potrebne radnje za osiguranje učinkovitosti tog prava, posebno kad se radi o pravu na istinu o tome što se dogodilo u slučajevima teških povreda ljudskih prava, kao što su to prisilni nestanci i izvansudska pogubljenja u ovom predmetu. Tvrditi u sudskom postupku, kao što je to učinjeno u ovom slučaju, da nedostaju dokazi o postojanju određenih informacija, bez da se u najmanju ruku istakne koji su postupci provedeni kako bi se potvrdilo nepostojanje tih informacija, omogućuje diskrecijsko i arbitrarno postupanje države u pružanju tih informacija, čime se stvara pravna nesigurnost u pogledu ostvarivanja tog prava.“"62 $\mathrm{Na}$ temelju navedenog obrazloženja, Međuamerički sud je zaključio da je država povrijedila pravo traženja i primanja informacija zajamčeno u članku 13. Američke konvencije u vezi s člankom 1. stavkom 1. (obveza poštovanja prava), člankom 8 . stavkom 1 . (pravo na pošteno suđenje) i člankom 25. (pravo na sudsku zaštitu). ${ }^{63}$

58 Članak 8. stavak 1. glasi: "Svaka osoba ima pravo na saslušanje, uz dužna jamstva i u razumnom roku, od strane nadležnog, nezavisnog i nepristranog suda (engl. tribunal), prethodno ustanovljenog zakonom, u ispitivanju bilo kakve optužbe kažnjive naravi protiv njega ili radi utvrđivanja njegovih prava i obveza građanske, radne, fiskalne ili bilo kakve druge naravi."

59 Claude-Reyes et al. v. Chile, op. cit., par. 122-123.

60 Slučaj se odnosio na postupanje brazilske vojske između 1972. i 1975. sa svrhom likvidacije, tzv. Araguaia gerile. Propisi o pomilovanju zabranjivali su procesuiranje mučenja i ubijanja koja su se dogodila tijekom vojne diktature u Brazilu 1970-tih godina. Slučaj se, također odnosio na povredu prava članova obitelji žrtava na pristup informacijama.

61 Inter-American Court of Human Rights, Gomes Lund et al. ("Guerrilha do Araguaia") v. Brazil, Judgment of November 24, 2010, par. 201.

62 Ibid., par. 211.

63 Ibid., par. 212. 
Ako usporedimo stajališta Odbora za ljudska prava UN-a te Međuameričkog suda za ljudska prava u predmetima koja su se odnosila na pravo na pristup informacijama s osnovnim karakteristikama toga prava izloženima u poglavlju 1.1. ovoga rada dolazimo do sljedećih zaključaka. Kao prvo, navedena međunarodna tijela smatraju da izričito propisivanje prava tražiti i primiti informacije štiti pravo tražiti informacije koje posjeduje država, uz iznimke koje su dopuštene putem ograničenja koja su utvrđena u Paktu i u Američkoj konvenciji. To znači da nije potrebno da se osoba pozove na povredu nekoga drugog prava zaštićenog Paktom ili Američkom konvencijom (primjerice, na pravo na poštovanje privatnog života ili pravo na život), da bi se njezin predmet podveo pod zaštitu tih međunarodnih ugovora. U tom smislu, pravo na pristup informacijama samostalno je ljudsko pravo, a zaštićeno je člankom 19. Pakta odnosno člankom 13. Američke konvencije.

Kao drugo, ne bi trebala postojati ograničenja u tomu kome to pravo pripada. Naime, i članak 19. Pakta i članak 13. Američke konvencije propisuju da svatko ima pravo na slobodu izražavanja. Međutim, u predmetu Toktakunov protiv Kirgistana Odbor za ljudska prava istaknuo je funkciju podnositelja kao „,̌uvara“ o pitanjima od javnog interesa te je naveo da je podnositelj, kao pravni savjetnik u udruzi, dostatno potkrijepio okolnost da je on kao pojedini pripadnik javnosti izravno pogođen odbijanjem tijela javne vlasti da mu pruži zatražene informacije. Ono što je pozitivno jest da je Odbor za ljudska prava jasno istaknuo da funkciju, „čuvara“ ne ispunjavaju samo udruge, već da to mogu činiti i ,privatni pojedinci“. ${ }^{64} \mathrm{Za}$ razliku od toga, Međuamerički sud naveo je da članak 13. Konvencije ,štiti pravo svake osobe da zatraži informaciju pod kontrolom države, uz uvjete koji su dopušteni pod režimom ograničenja Konvencije“. ${ }^{65}$ Drugim riječima, za Međuamerički sud nije bitno tko je podnositelj zahtjeva da bi primijenio članak 13., dok je za Odbor za ljudska prava - barem prema dosadašnjoj praksi - potrebno potkrijepiti zašto je pripadnik javnosti kojemu je uskraćen pristup informacijama izravno pogođen time. U protivnom bi se priopćenje podnositelja proglasilo nedopuštenim jer bi se smatralo da predstavlja actio popularis. U tom smislu vidljivo je da Međuamerički sud pruža širu zaštitu tj. većem krugu osoba, koji ne moraju dokazivati svoju funkciju ,čuvara“ (ili zbog nekog drugog razloga) da bi se na njih primijenila zaštita koju pruža članak 13. Američke konvencije.

Kao treća karakteristika prava na pristup informacijama ${ }^{66}$ navedena je irelevantnost naravi informacije, tj. važno je da je riječ o informaciji koju posjeduju tijela javne vlasti, a nebitno je kakva je informacija. Pitanje koje se ovdje postavlja je mora li biti riječ o informaciji koja zadovoljava određenu kvalitetu javnog interesa da bi se mogla primijeniti zaštita koju pruža članak 19. Međunarodnog pakta odnosno članak 13. Američke konvencije? U predmetu Toktakunov protiv Kirgistana, Odbor za ljudska prava napomenuo je da je bila riječ o uskrati pristupa

64 Toktakunov v. Kyrgyzstan, op. cit., par. 7.4.

65 Gomes Lund et al. ("Guerrilha do Araguaia") v. Brazil, op. cit., par. 197.

66 V. poglavlje 1.1. ovoga rada. 
informacijama od javnog interesa. ${ }^{67}$ Dodatno, u dijelu svoje odluke koji se odnosio na razmatranje dopuštenosti priopćenja Odbor je utvrdio da se informacije koje je podnositelj zatražio (broj osoba koje su osuđene na smrtnu kaznu u Kirgistanu) smatraju od javnog interesa prema Rezolucijama br. 2003/67 i 2004/60 Komisije za ljudska prava te Dokumentu iz Kopenhagena koji je potpisao Kirgistan. ${ }^{68}$ Dakle, Odbor se prvo bavio pitanjem naravi informacija te je utvrdio da mora biti riječ o informacijama od javnog interesa da bi uopće priopćenje proglasio dopuštenim i nastavio razmatrati meritum predmeta.

Što se tiče stajališta Međuameričkog suda, $u$ predmetu Claude Reyes $i$ drugi protiv Čilea napomenuo je da mora biti riječ o informaciji od javnog interesa. ${ }^{69}$ Međutim, na drugom mjestu u toj presudi, ${ }^{70}$ kao i u presudi u predmetu Gomes Lund i drugi protiv Brazila, ističe da članak 13. Američke konvencije jamči pravo na pristup informacijama koje posjeduje država ili koje su pod kontrolom države, bez da spominje da se mora raditi o informacijama od javnog interesa. Mišljenje autorice jest da prosuđivanje je li neka informacija od javnog interesa ne smije biti primarni uvjet za omogućavanje pristupa informacijama koje posjeduju tijela javne vlasti. Pitanje koliko je neka informacija od javnog interesa postaje bitno tek ako će primijeniti neki od dopuštenih razloga za ograničenje pristupa informacijama. Za razliku od Odbora za ljudska prava, čini se da Međuamerički sud ima takvo stajalište. U predmetu Gomes Lund i drugi protiv Brazila, javni interes se spominje jedino u vezi s postavljanjem ograničenja pristupa informacijama koja moraju biti nužna u demokratskom društvu te orijentirana prema zadovoljavanju prevladavajućega javnog interesa (pri čemu se navode razlozi iz članka 13. stavka 2. Američke konvencije: poštovanje prava i ugleda drugih, zaštita državne sigurnosti, javnog reda, zdravlja ili morala). ${ }^{71}$

I na kraju, četvrta karakteristika prava na pristup informacijama jest nepostojanje obveze korisnika da navede razlog zbog kojeg traži pristup informacijama. $\mathrm{U}$ tom pogledu ne postoji nikakva razlika u stajalištima Odbora za ljudska prava i Međuameričkog suda. Oba međunarodna tijela navode da se zatražene informacije moraju pružiti bez potrebe dokazivanja izravnog interesa za primanje tih informacija, osim ako se primjenjuju legitimna ograničenja.

Iz navedene analize može se zaključiti da, prema sadašnjem stanju prakse, Međuamerički sud glede pitanja kome pripada pravo na pristup informacijama te kakva je narav zatražene informacije pruža širu zaštitu prava na pristup informacijama nego što to čini Odbor za ljudska prava UN-a, premda se radi o gotovo identičnim odredbama međunarodnih ugovora kojima se štiti to pravo.

67 Toktakunov v. Kyrgyzstan, op. cit., par. 6.5.

68 Ibid., par. 6.3.

69 Claude-Reyes et al. v. Chile, op. cit., par. 73.

70 Ibid., par. 77.

71 Gomes Lund et al. ("Guerrilha do Araguaia”) v. Brazil, op. cit., par. 229. 


\section{PRISTUP EUROPSKOG SUDA ZA LJUDSKA PRAVA ZAS̆TITI PRAVA NA PRISTUP INFORMACIJAMA}

Europska konvencija ne propisuje izrijekom pravo na pristup informacijama koje posjeduju tijela javne vlasti, a njezin članak 10. kojim se jamči pravo na slobodu izražavanja ${ }^{72}$ oblikovan je u jednom dijelu uže od članka 19. Međunarodnog pakta o građanskim i političkim slobodama te članka 13. Američke konvencije. Naime, za razliku od tih međunarodnih ugovora koji pod pravom na slobodu izražavanja navode slobodu traženja, primanja i širenja informacija, članak 10. Europske konvencije ne sadrži slobodu traženja, već samo slobodu primanja i širenja informacija. Krajem 1970-tih godina raspravljalo se o nacrtu dodatnoga protokola uz Europsku konvenciju kojim bi se pravo na slobodu izražavanju izričito proširilo na način da uključi i slobodu tražiti informaciju (freedom to seek information). Međutim, nacrt protokola nije dobio široku potporu te se od njega odustalo. ${ }^{73}$

Pitanje koje se pojavilo u predmetima koji su se pokrenuli pred Europskim sudom jest na što se točno odnosi odredba članka 10., tj. pokriva li ona pozitivnu obvezu države da pruža zatražene informacije. Kad se pogleda formulacija članka 10., moglo bi se smatrati da je on oblikovan kao pravo negativnog statusa koje obuhvaća pravnu situaciju pojedinca u koju država ne smije dirati. ${ }^{74}$ Naime, članak 10. jamči slobodu primanja i širenja informacija i ideja bez miješanja vlasti. Dakle, ta se odredba može shvatiti na način da propisuje da država nije ovlaštena spriječiti pojedinca da primi informaciju koju mu netko drugi želi priopćiti, ali da to ne mora značiti i da država ima pozitivnu obvezu pružiti informaciju koju posjeduje kada ju zatraži pojedinac. ${ }^{75}$

U početku svoje prakse Europski sud je upravo zauzeo takvo stajalište. Smatrao je da ne postoji pozitivna obveza države da osigura pravo na pristup informacijama u okviru prava na slobodu izražavanja zajamčenog člankom 10. Europske konvencije. Predmet koji se s tim u vezi ističe u literaturi je Leander protiv Švedske (1987.). U tom predmetu bitna je okolnost da se radilo o zahtjevu pojedinca

72 Članak 10. Europske konvencije glasi:

„1. Svatko ima pravo na slobodu izražavanja. To pravo obuhvaća slobodu mišljenja i slobodu primanja i širenja informacija i ideja bez miješanja javne vlasti i bez obzira na granice. Ovaj članak ne sprječava države da podvrgnu režimu dozvola ustanove koje obavljaju djelatnosti radija ili televizije te kinematografsku djelatnost.

2. Kako ostvarivanje tih sloboda obuhvaća dužnosti i odgovornosti, ono može biti podvrgnuto formalnostima, uvjetima, ograničenjima ili kaznama propisanim zakonom, koji su u demokratskom društvu nužni radi interesa državne sigurnosti, teritorijalne cjelovitosti ili javnog reda i mira, radi spriječavanja nereda ili zločina, radi zaštite zdravlja ili morala, radi zaštite ugleda ili prava drugih, radi spriječavanja odavanja povjerljivih informacija ili radi očuvanja autoriteta i nepristranosti sudbene vlasti.“

73 Coppel, P., op. cit., str. 83.

74 Borković, I., op. cit., str. 252-253.

75 Knight, C. J. S., Article 10 and a right of access to information, Public Law, July 2013, str. 469. 
za pristup informacijama koje se odnose na njega (osobne informacije). ${ }^{76}$ Europski sud je utvrdio sljedeće: "Sud primjećuje da pravo na slobodu primanja informacija u osnovi zabranjuje Vladi da ograničava osobu da primi informacije koje joj drugi žele ili su spremni dati. Članak 10. ne dodjeljuje pojedincu, u okolnostima poput onih u ovom predmetu, pravo pristupa registru koji sadrže informacije o njegovu osobnom položaju, niti utjelovljuje obvezu Vlade da mu takvu informaciju daju." ${ }^{177}$ Europski sud je taj predmet sagledavao i s aspekta jamstva prava na poštovanje privatnog $\mathrm{i}$ obiteljskog života (članak 8.), ali miješanje u to pravo je smatrao opravdanim zbog zaštite nacionalne sigurnosti. ${ }^{78}$ Stoga se pristup Europskog suda može objasniti tako da se razlikuju osobne informacije (informacije koje se odnose na neku osobu) i informacije koje nisu osobne, te se povreda prava na pristup osobnim informacijama razmatra temeljem članka 8 . kojim se jamči pravo na poštovanje privatnog života i doma. $^{79}$

Što se tiče članka 10., za njega je Europski sud dugo smatrao da ne pokriva pozitivnu obvezu države da osigura pravo na pristup informacijama. ${ }^{80}$ Tako je u predmetima Gaskin protiv Ujedinjenog Kraljevstva (1989.), ${ }^{81}$ Guerra i drugi protiv Italije (1998. $)^{82}$ te Roche protiv Ujedinjenog Kraljevstva (2005.) ${ }^{83}$ Europski sud citirao svoje stajalište iz presude u predmetu Leander protiv Švedske da članak 10. ne utjelovljuje pozitivnu obvezu države da pruža informacije pojedincu ${ }^{84}$ Međutim, ipak su ti predmeti bili presuđeni u korist podnositelja jer je Europski sud utvrdio da je došlo do povrede prava na poštovanje privatnog i obiteljskog života.

76 Ukratko, radilo se o gospodinu Leanderu koji je zatražio pristup informacijama koje su se odnosile na sigurnosnu provjeru, ali mu je uskraćen pristup.

77 Leander v. Sweden, Application no. 9248/81, 26 March 1987, par. 74.

78 Smerdel, B.; Gardašević, Đ., op. cit., str. 27-28.

79 Coppel, P., op. cit., str. 83.

80 Knight, C. J. S., op. cit. str. 469.

81 Graham Gaskin je kao beba završio u domu za nezbrinutu djecu gdje je proveo cijelo djetinjstvo do punoljetnosti. Gaskin je tvrdio da je bio zlostavljan za vrijeme koje je proveo pod skrbi te je zatražio pristup svom spisu od socijalne službe u Liverpoolu. Međutim, uvid mu je samo djelomično omogućen, jer su nadležna tijela uključujući i nacionalni sud smatrali da bi se omogućavanjem uvida ugrozila prava doušnika koji dostavljaju informacije socijalnoj službi.

82 U predmetu Guerra i drugi protiv Italije radilo se o talijanskim državljanima koji su živjeli otprilike jedan kilometar od kemijske tvornice koja je predstavljala visoki rizik za okoliš, a talijanska tijela javne vlasti nisu im priopćila relevantne informacije o opasnostima iz te tvornice niti o predviđenom postupku u slučaju nesreće.

83 U predmetu Roche radilo se o vojniku koju je bio izložen kemijskim testiranjima, tj. sudjelovao je u testiranju kemijskog oružja (nervnog plina), od čega je obolio te je tražio pristup informacijama o tim testovima.

84 Gaskin v. The United Kingdom, Application no. 10454/83, 07 July 1989, par. 52.; Guerra and others v. Italy, Application No. 14967/89, 19 February 1998, par. 53.; Roche v. The United Kingdom, Application no. 32555/96, 19 October 2005, par. 172. Važno je napomenuti je da postoji određena razlika između predmeta Gaskin, s jedne strane, te Guerra i Roche, s druge. U predmetu Gaskin radilo se o zatraženom pristupu osobnim podatcima, a u predmetima Guerra $i$ Roche, Europski sud istaknuo je da se članak 10. ne može tumačiti da nameće državi pozitivne obveze prikupljati i širiti informacija na vlastitu inicijativu. 
Može li Europski sud promijeniti svoj pristup zaštiti nekog prava? Odgovor na to pitanje je zasigurno potvrdan. S tim u vezi može se citirati dio iz presude velikog vijeća u predmetu Goodwin protiv Ujedinjenog Kraljevstva (2002.): "Iako Sud nije formalno vezan slijediti svoje prethodne presude, $u$ interesu je pravne sigurnosti, predvidljivosti i jednakosti pred zakonom da ne odstupi, bez opravdanog razloga, od presedana utvrđenih u prethodnim slučajevima (...). Međutim, budući da je Konvencija prije svega sustav za zaštitu ljudskih prava, Sud mora uzeti u obzir promjenjive uvjete unutar tužene države i unutar država ugovornica općenito i odgovoriti, na primjer, na bilo koji razvoj međusobnog približavanja standardima koje treba postići (...). Od presudne je važnosti da se Konvencija tumači i primjenjuje na način koji čini njezina prava praktičnima i djelotvornima, a ne teorijskima i iluzornima. Propust Suda da zadrži dinamičan i evolucijski pristup bi doista riskirao da ga učini preprekom reformiranju i poboljšanju." ${ }^{85}$

Prvi bitan predmet koji je ukazivao na promjenu pristupa Europskog suda u primjeni članka 10. jest Sdruženi Jihočeske matky protiv Češke (2006.). Slučaj se odnosio na udrugu za zaštitu okoliša koja je tražila pristup dokumentima koji su se odnosili na jednu nuklearnu elektranu. Pristup je bio odbijen. Iako je Europski sud u ovom predmetu presudio da nije bilo povrede članka 10., ipak je po prvi put izričito utvrdio da je odbijanje pristupa od strane čeških vlasti značilo miješanje u pravo primiti informacije. ${ }^{86}$ Europski sud objasnio je promjenu svog pristupa na sljedeći način: „U ovom slučaju, podnositeljica zahtjeva je zatražila dopuštenje da se konzultira s administrativnim dokumentima koji su bili na raspolaganju tijelima javne vlasti i kojima je bio moguć pristup pod uvjetima propisanim člankom 133. Zakona o gradnji koji je podnositeljica osporavala. Pod tim okolnostima, Sud priznaje da je odbijanje tog zahtjeva predstavljalo miješanje u pravo podnositeljice zahtjeva na primanje informacija.“" ${ }^{67}$ Podnositeljica zahtjeva ipak nije uspjela pred Europskim sudom, jer je Europski sud odlučio da su u konkretnom slučaju bili ispunjeni uvjeti iz stavka 2. članak 10. koji se odnose na ograničavanje prava. Europski sud je smatrao da je obrazloženje odbijanja pristupa dokumentima bilo opravdano zbog zaštite poslovne tajne (zaštita prava drugih) te je postojao rizik za nacionalnu sigurnost zbog opasnosti od terorističkih napada. Relevantni dio presude glasi: „Sud primjećuje da su odluke koje su češka tijela javne vlasti donijela u potpunosti opravdane i ne mogu se smatrati arbitrarnima. On napominje da se okolnosti ovog slučaja jasno razlikuju od onih slučajeva koji se odnose na ograničenja slobode tiska, u kojem je više puta potvrdio postojanje prava javnosti da primi informacije. Međutim, ovaj slučaj u pitanju odnosi se na pristup informacijama vezanim uz nuklearnu elektranu, koja je objekt visoke složenosti koji

85 Christine Goodwin v. The United Kingdom, Application no. 28957/95, 11 July 2002, par. 74.

86 Hins, W.; Voorhoof, D., Access to State-Held Information as a Fundamental Right under the European Convention on Human Rights, European Constitutional Law Review 3(1), 2007., str. 123.

87 Décision sur la recevabilité de la requête no 19101/03 présentée par Sdružení Jihočeské matky contre la République tchèque, 10 juillet 2006, En droit, par. 1.1. 
zahtijeva vrlo visok stupanj sigurnosti. Sud smatra da se članak 10. Konvencije ne može tumačiti kao da jamči apsolutno pravo pristupa svim tehničkim pojedinostima izgradnje elektrane, jer, za razliku od podataka o utjecaju na okoliš, takvi podaci ne ispunjavaju javni interes. “88 No, neovisno o tomu što je Europski sud taj slučaj proglasio nedopuštenim, ipak je predmet iznimno važan jer je došlo da primjene članka 10. Europske konvencije na odbijanje pristupa informacijama.

Prvi put je presuđeno da je povrijeđen članak 10. u predmetu Társaság a Szabadságjogokért (dalje: Társaság) protiv Mađarske (2009.). ${ }^{89}$ Podnositeljica zahtjeva bila je udruga koja je aktivna na području politike o drogama. U ožujku 2004., član parlamenta (zastupnik) i drugi pojedinci podnijeli su Ustavnom sudu zahtjev za apstraktnu ocjenu ustavnosti nekih izmjena i dopuna Kaznenog zakonika koje su se ticale određenih kaznenih djela povezanih s drogama. Udruga Társaság zatražila je pristup tom zahtjevu koji je podnesen pred Ustavnim sudu, ali je pristup bio odbijen jer se radi o osobnim podatcima kojima se ne može pristupiti bez odobrenja autora toga zahtjeva. U obrazloženju presude Europski sud je istaknuo da je u nedavno vrijeme napredovao prema širem tumačenju pojma „sloboda primanja informacija“ (u predmetu Sdruženi Jihočeské matky protiv Češke) i, time, prema priznavanju prava na pristup informacijama..$^{90}$ Međutim, zaključio je da se ovaj predmet odnosio na upletanje - putem cenzorskih ovlasti informacijskog monopola - u ostvarivanje funkcija „društvenog čuvara“, a ne na uskratu općeg prava na pristup službenim dokumentima. ${ }^{91}$ Važnost presude je u tomu što je Europski sud proširio tradicionalnu zaštitu medija kao „javnih čuvara“ i na nevladine organizacije koje naziva „društvenim čuvarima““.92 U presudi je utvrđena obveza države ne sprječavati protok informacija potrebnih za javnu raspravu o pitanjima od javnog značenja: „Sud smatra da prepreke stvorene kako bi spriječile pristup informacijama od javnog interesa mogu odvratiti one koji rade u medijima ili povezanim područjima od bavljenja tim stvarima. Kao posljedica toga može se dogoditi da oni više nisu u mogućnosti igrati vitalnu ulogu ,javnih čuvara“, a njihova sposobnost pružanja točnih i pouzdanih informacija može biti izložena negativnom djelovanju (...). Navedena razmatranja dovela su Sud do zaključka da se upletanje u slobodu izražavanja podnositeljice u ovom slučaju ne može smatrati nužnim u demokratskom društvu. Iz toga slijedi da je došlo do povrede članka 10. Konvencije." "93

Nakon predmeta Társaság slijedio je niz presuda u kojima je Europski sud presudio da je također došlo do povrede članka 10. Konvencije: Kenedi protiv

88 Ibid.

89 Társaság a Szabadságjogokért v. Hungary, Application no. 37374/05, 14 April 2009; za prijevod presude v.: Staničić i Ofak, 2009: 527-536.

90 Ibid., par. 35.

91 Ibid., par. 36.

92 Ibid., par. 27.

93 Ibid., par. 38-39. 
Mađarske (2009.), ${ }^{94}$ Inicijativa mladih za ljudska prava protiv Srbije (2013.), ${ }^{95}$ Österreichische Vereinigung zur Erhaltung, Stärkung und Schaffung eines wirtschaftlich gesunden land- und forstwirtschaftlichen Grundbesitzes (dalje: ÖVESSG) protiv Austrije (2013. $)^{96}$ te Guseva protiv Bugarske (2015.) ${ }^{97}$

Usporedba presuda Europskog suda s odlukama Odbora za ljudska prava UN-a te Međuameričkog suda za ljudska prava dovodi nas do zaključka da postoje dodirne točke u načinu pružanja zaštite prava na pristup informacijama, ali i da je praksa Europskog suda u određenim pitanjima različita od Odbora za ljudska prava i Međuameričkog suda. Sličnosti i razlike su sljedeće. Kao prvo, i Odbor i

94 Kenedi v. Hungary, Application no. 31475/05, 26 May 2009. Podnositelj zahtjeva je u svrhu povijesnog istraživanja zatražio od Ministarstva unutarnjih poslova da mu se omogući pristup određenim dokumentima koji se odnose na djelatnosti mađarske Službe za nacionalnu sigurnost 1960.-tih godina. Njegov zahtjev odbijen je s obrazloženjem da su dokumenti klasificirani kao državna tajna do 2048. Nakon što je podnositelj zahtjeva dobio sudsku presudu kojom je odobren pristup dokumentima, Ministarstvo je osporavalo opseg pristupa. Uvjetovalo je pristup potpisivanjem obveze povjerljivosti te je zabranilo podnositelju zahtjeva da objavi podatke u mjeri u kojoj su u pitanju "državne tajne". Zatim su, u skladu $\mathrm{s}$ izvornom sudskom presudom, domaći sudovi presudili u korist podnositelja u naknadnim postupcima za izvršenje presude te su odredili novčanu kaznu Ministarstvu. Unatoč tomu, podnositelj zahtjeva nije ostvario neograničen pristup jednom od dokumenata.

95 Youth Initiative for Human Rights v. Serbia, Application no. 48135/06, 25 June 2013. Inicijativa mladih za ljudska prava (udruga) zatražila je od Sigurnosno-obavještajne agencije pristup informacijama o tomu koliko je ljudi bilo pod elektroničkim nadzorom te agencije u 2005. Agencija je prvo odbila zahtjev, pozivajući se na zakonske odredbe koje se primjenjuje na državnu, službenu ili drugu tajnu. Temeljem žalbe Inicijative, Povjerenik za informacije donio je odluku da je agencija povrijedila odredbe Zakona o slobodnom pristupu informacijama od javnog značaja i naredio agenciji da omogući žaliteljici pristup traženim informacijama. Agencija je naposljetku obavijestila Inicijativu da ne posjeduje tražene informacije.

96 ÖVESSG v. Austria, Application no. 39534/07, 28 November 2013. ÖVESSG je udruga koja ima za cilj proučavanje prijenosa vlasništva poljoprivrednog i šumskog zemljišta radi procjene utjecaja takvih prijenosa na društvo. Udruga je zatražila od Tirolske komisije za promet nekretnina da joj omogući pristup, poštom, svim odlukama koje je donijela od 1. siječnja 2000. godine. Udruga je bila spremna nadoknaditi troškove slanja odluka. Međutim, Komisija je odbila pristup traženim informacijama, tvrdeći da anonimizirane odluke ne predstavljaju podatke u smislu članka 1. stavka 2. Zakona o pristupu informacijama. Komisija je i tvrdila da bi pružanje informacija (anonimiziranje odluka i njihovo dostavljanje) zahtijevalo toliko resursa da bi to utjecalo na obavljanje javnih ovlasti Komisije. Upravni sud odbacio je tužbu s obrazloženjem da nije nadležan za predmetnu tužbu protiv odluke Komisije, a Ustavni sud potvrdio je odluku Komisije.

97 Guseva v. Bulgaria, Application no. 6987/07, 17 February 2015. Podnositeljica zahtjeva članica je odbora Društva za zaštitu životinja u Vidinu, Bugarskoj. Između travnja 2002. i lipnja 2003. godine podnijela je tri zahtjeva gradonačelniku Vidina za pristup informacijama vezanim uz liječenje i postupanje sa životinjama lutalicama. Gradonačelnik je odbio dati tražene informacije, s obrazloženjem da društvo s kojim je sklopljen ugovor nije dalo svoj pristanak za objavu informacija te da se dio informacija odnosio na postupak javne nabave. Podnositeljica je na kraju ishodila tri presude od Vrhovnog upravnog suda u svoju korist. Međutim, budući da usprkos presudama nije dobila zatražene informacije, podnijela je zahtjev Europskom sudu. 
Međuamerički sud smatraju da je pravo tražiti informacije koje posjeduje država zajamčeno člancima Pakta odnosno Američke konvencije koji se odnose na slobodu izražavanja. S druge strane, u najnovijoj presudi Guseva protiv Bugarske, Europski sud „primjećuje da se članak 10. ne može tumačiti kao da jamči opće pravo na pristup informacijama." ${ }^{\text {"98 }}$ No, to ne znači da taj članak nije primjenjiv na slučajeve koji se odnose na uskratu pristupa informacijama, kao što je vidljivo iz presuda Europskog suda u gore spomenutim predmetima: „Istovremeno, Sud je dosljedno naglašavao da članak 10. ne jamči samo pravo na priopćavanje informacija, već $i$ pravo javnosti da ih primi ... S tim u vezi je smatrao da se moraju pružiti osobito jaki razlozi za svaku mjeru koja ograničava pristup informacijama koje javnost ima pravo primiti ....".99

Kao drugo, iako ne bi trebala postojati ograničenja u tomu kome pravo na pristup informacijama pripada, jer to pravo pripada svakome, uočene su razlike u praksi Odbora za ljudska prava i Europskog suda s jedne strane, te Međuameričkog suda s druge. Za Međuamerički sud nije bitno tko je podnositelj zahtjeva da bi primijenio članak 13. o slobodi izražavanja, za razliku od Odbora za ljudska prava te Europskog suda koji razmatraju okolnosti vezane uz podnositelja zahtjeva kojemu je uskraćen pristup informacijama. Tako je Europski sud u prethodno spomenutim predmetima prvo utvrdio da se radi o nevladinim organizacijama koje su uključene u pitanja od javnog interesa, pri čemu ostvaruju svoju ulogu javnog odnosno društvenog čuvara (Társaság, Inicijativa mladih za ljudska prava te ÖVESSG), o povjesničaru koji želi objaviti istraživanje (Kenedi) te fizičkoj osobi, članici udruge, koja želi informacije potrebne da ostvari svoju ulogu informiranja javnosti o pitanjima općeg interesa i doprinosa javnoj debati (Guseva). Tek nakon što je utvrdio o kome se radi, zaključio je da je došlo do miješanja u pravo podnositelja zahtjeva, a zatim je odlučivao je li takvo miješanje bilo opravdano. U tom pogledu, Europski sud te Odbor za ljudska prava UN-a imaju isto stajalište da je pravo na pristup informacijama koje proizlazi iz slobode izražavanja povezano $\mathrm{s}$ ostvarenjem određenih uloga koje tražitelji informacija imaju u društvu. ${ }^{100}$ Isto se može zaključiti i u vezi s naravi informacija koje se traže - one za Europski sud i za Odbor za ljudska prava moraju ispunjavati određenu kvalitetu javnog (općeg) interesa. Tu okolnost Europski sud napominje u svojim predmetima: „Sud dosljedno priznaje da javnost ima pravo dobiti informacije od općeg interesa. “101 Dakle, Europski sud prvo utvrđuje da se radilo o traženju informacija od javnog interesa, ${ }^{102}$ da bi zaključio da je došlo do miješanja u pravo na primanje i širenje informacija zajamčeno člankom 10.

98 Ibid., par. 36.

99 Ibid.

100 Usp. McDonagh, M., op. cit., str. 47.

101 ÖVESSG v. Austria, op. cit., par. 33.

102 Primjerice, ibid., par. 36.; Youth Initiative for Human Rights v. Serbia, op. cit., par. 24; Guseva v. Bulgaria, op. cit., par. 55. 
I naposljetku, i Odbor za ljudska prava i Međuamerički sud smatraju da se zatražene informacije moraju pružiti bez potrebe da se dokaže izravni interes za primanje tih informacija. Europski sud o tomu dosad ništa nije rekao, budući da nije još ni potvrdio da se zaista člankom 10. Europske konvencije jamči opće pravo na pristup informacijama.

\section{PRAKSA USTAVNOG SUDA REPUBLIKE HRVATSKE POVODOM USTAVNIH TUŽBI}

U svrhu istraživanja prakse Ustavnog suda u vezi s postupcima po Zakonu o pravu na pristup informacijama koji su prethodili ustavnosudskom postupku provedena je analiza 49 odluka i rješenja Ustavnog suda donesenih u razdoblju od srpnja 2008. do srpnja $2014 .{ }^{103}$ Od toga je 71,43 \% ustavnih tužbi odbačeno, 28,57 $\%$ odbijeno, a nijedna ustavna tužba nije bila usvojena.

Analizom je utvrđeno da se u svim slučajevima u kojima je Ustavni sud donio rješenje o odbacivanju (ukupno 35 rješenja) radilo o ustavnim tužbama koje su odbačene jer nisu postojale pretpostavke za odlučivanje o ustavnopravnoj biti stvari. Naime, Ustavni sud je u prosincu 2009. započeo s restriktivnijim odlučivanjem o pretpostavkama za podnošenje ustavnih tužbi. ${ }^{104}$ Osnova za odbacivanje je članak 32. Ustavnog zakona o Ustavnom sudu Republike Hrvatske ${ }^{105}$ (dalje: Ustavni zakon), koji propisuje da će Ustavni sud rješenjem odbaciti ustavnu tužbu u drugim slučajevima kad ne postoje pretpostavke za odlučivanje o biti stvari. Pod „odlučivanjem o biti stvari“ u smislu toga članka razumijeva se odlučivanje o ustavnopravnoj biti stvari. Takav je zaključak povezan s člankom 71. stavku 2. Ustavnog zakona, sukladno kojem se ustavna tužba neće uzeti u razmatranje u slučaju kad se ne radi o povredi ustavnog prava. Rješenje o odbacivanju donosi vijeće za rješavanje pretpostavki za odlučivanje o ustavnim tužbama, u sastavu od tri suca od kojih je jedan predsjednik vijeća. ${ }^{106} \mathrm{U}$ svim svojim rješenjima o odbacivanju ustavnih tužbi Ustavni sud navodi sljedeće obrazloženje:

„Ustavna tužba nije redovni ili izvanredni pravni lijek u sustavu domaćih pravnih lijekova. Ona je posebno ustavnopravno sredstvo zaštite ustavnih prava u pojedinačnim slučajevima. Stoga nije dostatno pozvati se u ustavnoj tužbi na povrede koje su rezultat navodnih nezakonitosti što ih je počinilo nadležno tijelo ili sud u sudskom postupku. Protiv takvih nezakonitosti pravnu zaštitu pružaju redovni i specijalizirani sudovi u postupcima ustrojenim u više stupnjeva sudske zaštite.

103 Ovaj period analize temelji se na rješenjima i odlukama Ustavnog suda čiji je pristup autorici omogućila voditeljica Centra za evidenciju i dokumentaciju Ustavnog suda Republike Hrvatske.

104 V. rješenje broj: U-III-1747/2009 od 10. studenoga 2009.

105 NN, br. 99/1999, 29/2002 i 49/2002.

106 Sukladno članku 68. stavku 2. Ustavnog zakona, Vijeće sastavljeno od troje sudaca odlučuje o ustavnim tužbama kada ne postoje postupovne pretpostavke za odlučivanje (nepravodobnost, neovlaštenost na podnošenje ustavne tužbe, nedopuštenost i dr.). 
One iznimno mogu biti i predmet ispitivanja pred Ustavnim sudom, ali samo ako i u mjeri u kojoj mogu povrijediti ljudska prava i temeljne slobode zaštićene Ustavom.

U ustavnoj tužbi također nije dostatno ponoviti razloge koji su već istaknuti u žalbenim ili revizijskim postupcima pred sudom niti je dostatno samo navesti ustavna prava koja se smatraju povrijeđenima. Ustavna tužba mora sadržavati konkretne i obrazložene razloge eventualne povrede određenog ustavnog prava.

Konačno, kad je riječ o ustavnom jamstvu jednakosti pred zakonom, vlastiti slučaj valja dovesti, kad god je to moguće, u vezu s ostalim sličnim slučajevima i obrazložiti u čemu je on ustavnopravno specifičan da bi morao biti ispitan pred Ustavnim sudom." 107

Ustavni sud zatim navodi i o čemu se u konkretnim slučajevima radilo te se svi predmeti u kojima je ustavna tužba bila odbačena mogu svrstati u pet kategorija:

(a) u $34.3 \%$ predmeta dostupnost informacije za podnositelja je moguća primjenom drugih propisa (Prekršajnog zakona, Zakona o parničnom postupku, Zakona o općem upravnom postupku, Zakona o kaznenom postupku itd.),

(b) u $31.4 \%$ predmeta utvrđeno je da je Upravni sud pravilno primijenio Zakon o zaštiti osobnih podataka ili drugi mjerodavni zakon koji propisuje koji su podatci službena tajna ili se radilo o uskrati informacija koje su se ticali kaznenog ili predkaznenog postupka koji je u tijeku odnosno informacije su bile uskraćene zbog zaštite učinkovitog vođenja upravnog postupka;

(c) u $25.7 \%$ predmeta utvrđeno je da je stranci omogućen pristup informacijama odnosno dostavljena tražena informacija;

(d) u $5.7 \%$ predmeta tužba u upravnom sporu bila je ispravno odbačena jer nije bio iscrpljen redovni pravni lijek (žalba u upravnom postupku) ili je tužba bila preuranjena;

(e) u $2.9 \%$ predmeta radilo se o tomu da je zahtjev za pristup informacijama bio ustupljen nadležnom tijelom, a podnositelj je izjavljivao pravne lijekove (sredstva) protiv tog ustupanja.

Svoja rješenja Ustavni sud završava na sljedeći način (s međusobno vrlo sličnim varijacijama): „Ustavni sud utvrđuje da se osporavajući razlozi sadržani u ustavnoj tužbi iscrpljuju u žalbenim odnosno razlozima tužbe kojom je pokrenut upravni spor, a na koje su nadležna tijela, te Upravni sud u osporenim odlukama već odgovorila, dok se navodno postojanje povreda istaknutih ustavnih prava ne obrazlaže.“108 „Podnositelj u ustavnoj tužbi nije pokazao da Visoki upravni sud Republike Hrvatske u svojem postupanju ili pri donošenju presude nije poštovao odredbe Ustava o ljudskim pravima i temeljnim slobodama, odnosno da je proizvoljno protumačio mjerodavne odredbe zakona ili drugih propisa. Ustavni sud stoga ocjenjuje da konkretan slučaj ne otvara pitanje ostvarenja ustavnih prava

107 Rješenje broj: U-III-5427/2008 od 25. ožujka 2010.

108 Rješenje broj: U-III-2807/2008 od 14. travnja 2011. Napomena: radilo se o postupku koji se vodio po Zakonu o pravu na pristup informacijama iz 2013. (NN, br. 172/2003), a sudska zaštita tada je bila osigurana pred Upravnim sudom Republike Hrvatske (sada: Visokim upravnim sudom Republike Hrvatske). 
podnositeljice. Stoga ne postoji ustavnopravna bit stvari o kojoj bi Ustavni sud odlučivao." ${ }^{109}$

Kada se sagleda tko su podnositelji ustavnih tužba, gotovo uvijek se radi fizičkim osobama, a samo u dva predmeta radilo se o pravnim osobama (jedan predmet - trgovačka društva te jedan predmet - vjerska zajednica).

Nadalje, zanimljivo je i sagledati na povredu kojih prava su se pozivali podnositelji ustavnih tužbi, a uzimajući u obzir da je Promjenom Ustava 2010. pravo na pristup informacijama koje posjeduju tijela javne vlasti uvršteno u glavu Ustava koja se odnosi na ljudska prava i temeljne slobode. Od tada je nadležnost Ustavnog suda u tom segmentu izravna. ${ }^{110} \mathrm{U}$ analiziranim ustavnim tužbama (ukupan broj: 17) koje su podnesene protiv presuda ili rješenja Upravnog suda Republike Hrvatske odnosno Visokog upravnog suda Republike Hrvatske donesenih nakon Promjene Ustava 2010. godine, podnositelji su navodili da su im osporenim pojedinačnim aktom povrijeđena sljedeća ustavna prava: ${ }^{111}$

(a) pravo na pristup informacijama (članak 38. stavak 4.) u $53 \%$ predmeta;

(b) pravo na pravično suđenje (članak 29. stavak 1.) u 53 \% predmeta;

(c) jamstvo sudske kontrole zakonitosti pojedinačnih akata javnopravnih tijela (članak 19. stavak 2.) u $41 \%$ predmeta;

(d) jednakost svih pred zakonom (članak 14. stavak 2.) u $35 \%$ predmeta.

U vrlo neznatnom broju predmeta podnositelji su se pozivali i na povredu:

(a) najviših vrednota ustavnog poretka (članak 3.) jedan predmet;

(b) načela razmjernosti (članak 16. stavak 2.) dva predmeta;

(c) prava na žalbu protiv pojedinačnih prvostupanjskih pravnih akata (članak 18. stavak 1.) tri predmeta;

(d) jednakost državljana Republike Hrvatske i stranaca pred javnopravnim tijelima (članak 26.) dva predmeta;

(e) prava na slanje predstavki, pritužbi i prijedloga (članak 46.) jedan predmet;

(f) prava vlasništva (članak 48. stavak 1.) jedan predmet;

(g) poduzetničkih i tržišnih sloboda te jednakosti pravnog položaja poduzetnika (članak 49.) jedan predmet;

(h) prava na zdrav život i osiguranja uvjeta za zdrav okoliš (članak 69. stavci 1. i 2.) jedan predmet.

U samo $23,5 \%$ predmeta podnositelji su smatrali da su osporenim aktima povrijeđene odredbe Europske konvencije. Međutim, nitko od podnositelja nije se pozvao na povredu prava na slobodu izražavanja već na povredu prava na pošteno suđenje (članak 6. stavak 1.) četiri predmeta te prava na djelotvoran pravni lijek (članak 13.) jedan predmet.

Prije Promjene Ustava 2010. (ukupan broj ustavnih tužbi: 32) dominantni razlozi za podnošenje ustavnih tužbi odnosno povrede na koje su se podnositelji pozivali bili su:

109 Rješenje broj: U-III-432/2014. od 20. ožujka 2014.

110 Gardašević, Đ., op. cit., str. 157.

111 Napomena: u pravilu se podnositelji pozivaju na nekoliko povreda, odnosno iznimno rijetko se pozivaju na povredu samo jednoga ustavnog prava. 
(a) pravo na pravično suđenje (članak 29. stavak 1.) - u $53 \%$ predmeta;

(b) jamstvo sudske kontrole zakonitosti pojedinačnih akata javnopravnih tijela (članak 19. stavak 2.) - u $47 \%$ predmeta;

(c) jednakost svih pred zakonom (članak 14. stavak 2.) - u 47\% predmeta;

(d) jednakost državljana Republike Hrvatske i stranaca pred javnopravnim tijelima (članak 26.) - $34 \%$ predmeta.

Ostali razlozi (u manjem broju predmeta) odnosili su se na: pravo na slanje predstavki, pritužbi i prijedloga, pravo vlasništva, pravo na žalbu protiv pojedinačnih pravnih akata, načelo zakonitosti pojedinačnih akata javnopravnih tijela (članak 19. stavak 1.), zabrana diskriminacije (članak 14. stavak 1.), pravo nasljeđivanja (članak 48. stavak 4.), najviše vrednote ustavnog poretka te načelo razmjernosti. Ni u jednom predmetu nije bilo navoda o povredi Europske konvencije.

Od prosinca 2009., kada je počeo restriktivnije odlučivati o pretpostavkama za podnošenje ustavnih tužbi, pa do srpnja 2014. Ustavni sud donio je šest odluka o odbijanju ustavnih tužbi. Konkretno se radilo o sljedećim slučajevima:

(a) na predmet se uopće nije primjenjivao Zakon o pravu na pristup informacijama jer je podnositelj u zahtjevu tražio od tijela javne vlasti određena očitovanja i mišljenja, a ne informaciju u smislu toga Zakona (jedan predmet) odnosno radilo se o primjeni Zakona o javnom bilježništvu na što je podnositelj bio upućen, ali je svejedno podnio ustavnu tužbu (jedan predmet);

(b) nisu bile ispunjene procesne pretpostavke za vođenje upravnog spora temeljem članka 26. Zakona o upravnim sporovima (NN, br. 53/1991, 9/1992 i 77/1992) prema kojima je tužitelj bio dužan požuriti rješavanje svoje žalbe kod drugostupanjskog tijela, što nije učinio; ${ }^{112}$

(c) davanje traženih informacija u konkretnom bi slučaju moglo onemogućiti rad tijela koja vrše nadzor zakonitosti;

(d) zahtjev je bio ustupljen nadležnom tijelu, ali tužba u upravnom sporu svejedno je bila podnesena protiv tijela javne vlasti koje ne posjeduje informaciju i koje je ustupilo zahtjev nadležnom tijelu te obavijestilo podnositelja o tomu;

(e) tražene informacije su uskraćene zbog zaštite tajnosti izvora podataka sigurnosno-obavještajne agencije.

U navedenim predmetima Ustavni sud sagledavao je povredu najviših vrednota ustavnog poretka, jednakosti pred zakonom, prava na žalbu, jednakosti hrvatskih državljana i stranaca pred javnopravnim tijelima, prava na pravično suđenje, prava na pristup informacijama te prava vlasništva.

U odlukama u kojima je ustavnu tužbu ocjenjivao s aspekta povrede ustavnog prava na pristup informacijama, odluke ne sadrže nikakvo obrazloženje vezano uz članak 38. stavak 4. Ustava, već Ustavni sud u jednoj rečenici samo zaključuje da navedeno ustavno pravo nije povrijeđeno. ${ }^{113}$

112 Napomena: procesna pretpostavka požurivanja rješavanja žalbe nije više propisana u novom Zakonu o upravnim sporovima (NN, br. 20/2010, 143/2012 i 152/2014).

113 Odluke broj: U-III-3969/2011 od 24. listopada 2013., U-III-921/2012 od travnja 2012. te U-III-5250/2012 od 6. veljače 2014. 


\section{ZAKLJUČAK}

Jedan od glavnih ciljeva ovoga rada bio je da se utvrdi po čemu se uvjeti zaštite prava na pristup informacijama razlikuju prema Ustavu u usporedbi sa zaštitom koja je zajamčena Europskom konvencijom. Najuočljivije je da, za razliku od Europske konvencije koja izrijekom ne sadrži pravo na pristup informacija koje posjeduju tijela javne vlasti, to je pravo zajamčeno hrvatskim Ustavom. Stoga, Ustavnom sudu nije potrebno da to pravo ,pronalazi“ u drugim odredbama Ustava, već se fizičke i pravne osobe mogu izravno pozvati na povredu tog ustavnog prava zajamčenog člankom 38. stavkom 4. Ustava. S druge strane, Europski sud još uvijek je u fazi napredovanja prema priznavanju općega prava na pristup informacijama (v. predmet Guseva protiv Bugarske). Baš zbog toga što u hrvatskom Ustavu postoji izričito jamstvo prava na pristup informacijama te je ono tako zakonski uređeno da korisnik nije obvezan navesti razloge zašto traži pristup informaciji (članak 18. stavak 4. ZPPI-a), autorica smatra da Ustavni sud ne bi trebao primjenjivati praksu Europskog suda prema kojoj se, da bi uopće zaključio da je došlo do miješanja u pravo, mora raditi o pojedincima i nevladinim organizacijama koji su uključeni u pitanja od javnog interesa i žele o tomu informirati javnost, sudjelovati u raspravama ili ostvarivati svoju ulogu javnog (društvenog) čuvara. Ovo stajalište dodatno potkrjepljuje time što su jamstva sadržana u Europskoj konvenciji samo minimalni standard zaštite prava. Stranke Konvencije ne smiju pružiti razinu zaštite ljudskih prava koja bi bila niža od one koja se zahtijeva Konvencijom, ali su slobodne prijeći tu granicu i pružiti širu, tj. bolju zaštitu. Naime, članak 53. Europske konvencije propisuje da se ništa u ovoj Konvenciji neće tumačiti kao da ograničava ili ukida bilo koje ljudsko pravo i temeljnu slobodu koji su priznati zakonima neke visoke ugovorne stranke ili bilo kojim drugim sporazumom kojega je ona stranka. U državi u kojoj je priznato opće pravo na pristup informacijama u domaćem zakonodavstvu sudovi mogu na temelju tih odredaba riješiti sporove koji nastanu, te ne moraju „,izmišljati“ rješenja primjenom članka 10. Europske konvencije. ${ }^{114}$ To ne znači da presude Europskog suda nisu relevantne, jer sudovi moraju paziti da se pravo na pristup informacijama ostvaruje u skladu s člankom 10., odnosno da se to pravo ne ograničava na način koji bi bio protivan zajamčenom pravu na slobodu izražavanja. Dakle, praksa Europskog suda je relevantna i za Ustavni sud s aspekta da se razina zaštite prava ne smije spustiti ispod razine zajamčene Europskom konvencijom. Međutim, s obzirom na članak 38. stavak 4. Ustava te ZPPI, autorica smatra da je Ustavni sud dužan pružiti širu zaštitu pravu na pristup informacijama od one razine koja je, prema trenutnoj praksi Europskog suda, zajamčena člankom 10. Europske konvencije (o čemu je bilo riječi u poglavlju 3. ovoga rada).

Imajući u vidu analizirane odluke i rješenja Ustavnog suda u prethodnom poglavlju, može li se zaključiti da on u praksi doista pruža širu zaštitu od one koju pruža Europski sud? Kao što je prikazano u poglavlju 4., u najvećem broju slučajeva

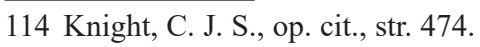


ustavna tužba bila je odbačena jer nisu postojale pretpostavke za odlučivanje o ustavnopravnoj biti stvari. U onom neznatnom broju slučajeva u kojima je došlo do meritornog odlučivanja o povredi ustavnog prava zajamčenog člankom 38. stavkom 4. (samo tri predmeta), Ustavni sud nije razmatrao tko traži informaciju, kakva je informacija i zašto mu ona treba, za razliku od Europskog suda kada odlučuje o povredi članka 10. Europske konvencije. Stoga bi se moglo zaključiti da za Ustavni sud nije bilo bitno treba li korisniku ta informacija zbog toga što o njoj želi informirati javnost, sudjelovati u raspravi ili ostvarivati svoju ulogu ,društvenog čuvara" te da pruža širu zaštitu, tj. širem krugu korisnika koji nisu obvezni imati neki opravdan razlog zbog kojeg traže pristup nekoj informaciji. Međutim, ipak postoji jedna bitna okolnost koja onemogućava donošenje definitivnih zaključaka o pristupu Ustavnog suda zaštiti prava na pristup informacija. Naime, u svojim odlukama Ustavni sud u samo jednoj šturoj rečenici navodi da ocjenjuje da u slučaju podnositelja ustavne tužbe navedeno pravo nije povrijeđeno. ${ }^{115}$ To nikako ne znači da je Ustavni sud pogriješio u svojoj ocjeni, ali bi neki minimum obrazloženja takve ocjene trebao dati imajući u vidu da članak 27. stavak 3. Ustavnog zakona propisuje da odluke i rješenja Ustavnog suda moraju biti obrazloženi. Ovako sami trebamo zaključiti zašto je (vjerojatno) Ustavni sud odlučio na način na koji je odlučio: jer je tužba u upravnom sporu bila podnesena protiv tijela koje ne posjeduje traženu informaciju i koje je zahtjev ustupilo nadležnom tijelu i o tomu obavijestilo podnositelja (predmet: U-III-3969/2011), jer se uopće nije radilo o primjeni ZPPI-a već Zakona o javnom bilježništvu (predmet: U-III-5250/2012), te jer se radilo o informaciji klasificiranoj stupnjem tajnosti sukladno zakonu (predmet: U-III-921/2012). U tom potonjem slučaju, baš zbog toga što je u pitanju bila primjena ograničenja prava na pristup informacijama iz ZPPI-a autorica smatra da je Ustavni sud trebao navesti da je ograničenje bilo u skladu sa ZPPI-om, razmjerno naravi potrebe za ograničenjem te nužno u slobodnom i demokratskom društvu ili je bar mogao konstatirati da su nadležna tijela (tada: Agencija za zaštitu osobnih podataka i Upravni sud Republike Hrvatske) pravilno primijenila test razmjernosti i javnog interesa. O takvim slučajevima Ustavni sud će imati priliku odlučivati u, nadamo se, skoroj budućnosti. ${ }^{116}$

I naposljetku, zašto bi bilo značajno da Europski sud postupi kao Međuamerički sud i prizna opće pravo na pristup informacijama? Dosadašnja praksa Europskog suda, kako je to istaknuo sudac Wojtyczek u svom izdvojenom mišljenju u presudi Guseva protiv Bugarske, zapravo dovodi do diskriminacije: "Sve to vodi do implicitnog priznanja dvaju krugova pravnih subjekata: povlaštena elita s posebnim pravom pristupa informacijama, i “obični puk", podvrgnut općem režimu koji omogućava veća ograničenja. ... Mi smo svi društveni čuvari koji nadziru djelovanje javne vlasti. Demokratsko društvo je - između ostalog -

115 Odluke broj: U-III-3969/2011 od 24. listopada 2013., U-III-921/2012 od 4. travnja 2012. te U-III-5250/2012 od 6. veljače 2014.

116 V. primjerice, ustavna tužba GONG-a iz veljače 2015. - <http://www.gong.hr/media/uploads/ ustavna_tuzba_patton_boggs_2015_final.pdf > (pristup: 9. listopada 2015.) 
zajednica društvenih čuvara. Stara razlika između novinara i drugih građana je danas opsoletna. ... Pristup informacijama ne bi trebao ovisiti o statusu osobe koja traži informacije. Pod pretpostavkom da je pravo zahtijevati pristup informacijama zaštićeno na temelju članka 10., razlika koja je učinjena u obrazloženju (presude Europskog suda u predmetu Guseva protiv Bugarske, op. a.) nespojiva je sa zabranom diskriminacije zajamčenom člankom 14. Konvencije." ${ }^{117}$

Pravo na pristup informacijama u današnje vrijeme nije kontroverzno pravo jer je šrroko prihvaćeno u pravnim sustavima zemalja diljem svijeta. Uvažavajući razvoj koji se zbiva na međunarodnoj razini (osobito u praksi Međuameričkog suda), te u zakonodavstvima stranaka Europske konvencije, činjenica da se u članku 10. Europske konvencije izrijekom ne spominje pravo traženja informacije ne bi se trebala tumačiti tako da pravo na pristup informacijama prema članku 10. ne pripada svima. Bit će zanimljivo pratiti hoće li se praksa Europskog suda razvijati u smjeru priznavanja općeg prava na pristup informacijama, jer - kao što je i sam Europski sud napomenuo - propuštanjem da zadrži dinamičan i evolucijski pristup riskirao bi da postane prepreka reformiranju i poboljšanju.

117 Guseva v. Bulgaria, op. cit., Dissenting opinion of Judge Wojtyczek, par. 7. 


\section{Summary}

\section{THE RIGHT OF ACCESS TO INFORMATION AS A RIGHT PROTECTED BY THE EUROPEAN CONVENTION AND OTHER INTERNATIONAL HUMAN RIGHTS TREATIES}

The paper presents the manner in which the right of access to information is protected by international treaties for the protection of human rights - the International Covenant on Civil and Political Rights and the American Convention on Human Rights. It analyses the case law of the United Nations Human Rights Committee and the Inter-American Court of Human Rights. Furthermore, it shows the development of the approach of the European Court of Human Rights to protecting the right of access to information under Article 10 of the European Convention for the Protection of Human Rights and Fundamental Freedoms. The comparison of the case law of the European Court with the decisions of the Human Rights Committee and the Inter-American Court leads to the conclusion that there is a common ground in the way of providing protection of the right of access to information, but also that the case law of the European Court in certain issues is different from the case law of the Human Rights Committee and the Inter-American Court. Finally, the paper explores the practice of the Croatian Constitutional Court in proceedings under the Croatian Right of Access to Information Act. The analysis of 49 decisions and rulings of the Constitutional Court adopted in the period from July 2008 to July 2014 is carried out. The paper ends with certain conclusions about the difference of conditions in protecting the right of access to information according to the Croatian Constitution and the European Convention and the level of protection of the rights that should be provided.

Keywords: access to information, freedom of expression, United Nations Human Rights Committee, Inter-American Court of Human Rights, European Court of Human Rights, Constitutional Court of the Republic of Croatia. 


\section{Zusammenfassung}

\section{RECHT AUF INFORMATIONSZUGANG ALS RECHT GESCHÜTZT DURCH DIE EUROPÄISCHE KONVENTION UND ANDEREN VERTRÄGEN FÜR MENSCHENRECHTSSCHUTZ}

In der Arbeit wird gezeigt auf welche Weise das Recht auf Informationszugang in den internationalen Verträgen für Menschenrechtschutz, im Internationalen Pakt über bürgerliche und politische Rechte und in der Amerikanischen Menschenrechtskonvention, geschützt ist. Es wird die Praxis des UNMenschenrechtsausschusses und des Interamerikanischen Gerichtshofs für Menschenrechte analysiert. Danach wird die Beitrittsentwicklung des Europäischen Gerichtshofs für Menschenrechte zum Schutz der Rechte auf Informationszugang laut Artikel 10. der Europäischen Konvention zum Schutz der Menschenrechte und Grundfreiheiten aufgezeigt. Der Vergleich der Rechtssprüche des Europäischen Gerichtshofs mit den Urteilen des Menschenrechtsausschusses und den Interamerikanischen Gerichtshofs für Menschenrechte lässt andeuten, dass es Berührungspunkte in der Weise der Schutzrechteanbietung auf Informationszugang gibt aber dass die Praxis des Europäischen Gerichtshofs in bestimmten Fragen unterschiedlich vom Menschenrechtsausschuss und dem Interamerikanischen Gerichtshof für Menschenrechte ist. Am Ende wird die Praxis des Bundesverfassungsgerichtes der Republik Kroatien in der Beziehung mit den Handlungsweisen laut dem Gesetz vom Recht auf Informationszugang, die einem verfassungsrechtlichen Verfahren vorangegangen sind, untersucht und es werden 49 Beschlüsse und Rechtssprüche des Bundesverfassungsgerichtes, die in der Zeitspanne vom Juli 2008 bis Juli 2014 gebracht wurden, analysiert. Die Arbeit endet mit bestimmten Schlussergebnissen des Unterschieds der Bedingungen des Schutzrechts auf Informationszugang laut dem Grundgesetz der Republik Kroatien und der Europäischen Konvention und der Schutzebene dieses Rechts, die gebeten werden sollte.

Schlüsselwörter: Recht auf Informationszugang, Meinungsfreiheit, UN-Menschenrechtsausschuss, Interamerikanische Gerichtshof für Menschenrechte, Europäischen Gerichtshofs für Menschenrechte, Bundesverfassungsgerichtes der Republik Kroatien. 


\section{Riassunto}

\section{DIRITTO ALL'ACCESSO ALLE INFORMAZIONI QUALE DIRITTO TUTELA DALLA CONVENZIONE EUROPEA E DAGLI ALTRI ACCORDI INTERNAZIONALI PER LA TUTELA DEI DIRITTI DELL'UOMO}

Nel lavoro si illustra il modo in cui il diritto all'accesso alle informazioni è tutelato negli accordi internazionali per la tutela dei diritti fondamentali - Patto internazionale sui diritti civili e politici e la Convenzione americana sui diritti dell'uomo. Si analizza la prassi del Consiglio per i diritti umani delle Nazioni Unite e della Corte interamericana per i diritti umani. Successivamente si espone l'evolversi dell'approccio della Corte europea dei diritti dell'uomo con riguardo alla tutela del diritto all'accesso alle informazioni secondo l'art. 10 della Convenzione europea per la salvaguardia dei diritti dell'uomo e delle libertà fondamentali. Il raffronto tra le sentenze della Corte europea e le decisioni del Consiglio per i diritti umani e della Corte interamericana conduce alla conclusione che esistano punti di raccordo nelle modalità di tutela del diritto all'accesso alle informazioni, ma anche alla conclusione che la giurisprudenza della Corte europea in determinate questioni sia diversa rispetto al Consiglio per i diritti umani ed alla Corte interamericana. Nella parte finale del contributo si esamina la giurisprudenza della Corte costituzionale della Repubblica di Croazia con riferimento ai procedimenti in forza della legge sul diritto all'accesso alle informazioni, i quali hanno preceduto il procedimento costituzionale e si analizzano le quarantanove decisioni e provvedimenti della Corte costituzionale adottate dal luglio del 2008 al luglio del 2014. Il contributo termina con determinate conclusioni circa le differenze delle condizioni di tutela del diritto all'accesso alle informazioni secondo la Costituzione della Repubblica di Croazia e la Convenzione europea e con riguardo al grado di tutela che tale diritto dovrebbe vedersi garantito.

Parole chiave: diritto all'accesso alle informazioni, libertà di espressione, Consiglio per i diritti umani delle Nazioni Unite, Corte Interamericana dei diritti umani, Corte europea dei diritti dell'uomo, Corte costituzionale della Repubblica di Croazia. 